\title{
Article \\ Adoption Pathways for DC Power Distribution in Buildings ${ }^{\dagger}$
}

\author{
Vagelis Vossos ${ }^{1} *^{(\mathbb{D}}$, Daniel L. Gerber ${ }^{1}{ }^{(\mathbb{D}}$, Melanie Gaillet-Tournier ${ }^{1}$, Bruce Nordman ${ }^{1}$, Richard Brown ${ }^{1}\left({ }^{(}\right.$,

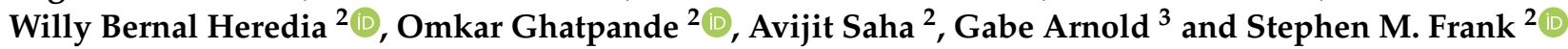

1 Lawrence Berkeley National Laboratory, 1 Cyclotron Rd, Berkeley, CA 94720, USA; dgerb@lbl.gov (D.L.G.); mgaillettournier@lbl.gov (M.G.-T.); bnordman@lbl.gov (B.N.); rebrown@lbl.gov (R.B.)

2 National Renewable Energy Laboratory, 15013 Denver West Parkway, Golden, CO 80401, USA; willy.bernalheredia@nrel.gov (W.B.H.); omkar.ghatpande@nrel.gov (O.G.); avijit.saha@nrel.gov (A.S.); Stephen.Frank@nrel.gov (S.M.F.)

3 Pacific Northwest National Laboratory, P.O. Box 999, Richland, WA 99352, USA; gabriel.arnold@pnnl.gov

* Correspondence: evossos@lbl.gov; Tel.: +1-510-495-2521

+ This paper is a technically extended version of a conference paper entitled "Direct-DC Power in Buildings: Identifying the Best Applications Today for Tomorrow's Building Sector", by a subset of the authors above, presented at the 2020 ACEEE Summer Study on Energy Efficiency in Buildings.

Citation: Vossos, V.; Gerber, D.L.; Gaillet-Tournier, M.; Nordman, B.; Brown, R.; Bernal Heredia, W.; Ghatpande, O.; Saha, A.; Arnold, G.; Frank, S.M. Adoption Pathways for DC Power Distribution in Buildings. Energies 2022, 15, 786. https:// doi.org/10.3390/en15030786

Academic Editor: Waqar Uddin

Received: 13 December 2021

Accepted: 19 January 2022

Published: 21 January 2022

Publisher's Note: MDPI stays neutral with regard to jurisdictional claims in published maps and institutional affiliations.

Copyright: (c) 2022 by the authors. Licensee MDPI, Basel, Switzerland. This article is an open access article distributed under the terms and conditions of the Creative Commons Attribution (CC BY) license (https:/ / creativecommons.org/licenses/by/ $4.0 /)$.
Abstract: Driven by the proliferation of DC energy sources and DC end-use devices (e.g., photovoltaics, battery storage, solid-state lighting, and consumer electronics), DC power distribution in buildings has recently emerged as a path to improved efficiency, resilience, and cost savings in the transitioning building sector. Despite these important benefits, there are several technological and market barriers impeding the development of DC distribution, which have kept this technology at the demonstration phase. This paper identifies specific end-use cases for which DC distribution in buildings is viable today. We evaluate their technology and market readiness, as well as their efficiency, cost, and resiliency benefits while addressing implementation barriers. The paper starts with a technology review, followed by a comprehensive market assessment, in which we analyze DC distribution field deployments and their end-use characteristics. We also conduct a survey of DC power and building professionals through on-site visits and phone interviews and summarize lessons learned and recommendations. In addition, the paper includes a novel efficiency analysis, in which we quantify energy savings from DC distribution for different end-use categories. Based on our findings, we present specific adoption pathways for DC in buildings that can be implemented today, and for each pathway we identify challenges and offer recommendations for the research and building community.

Keywords: feasibility of DC power distribution; efficient buildings; direct-DC; microgrids; renewable energy

\section{Introduction}

Since the war of the currents of the late 1800s, alternating current (AC) has dominated power distribution in the building sector. During the 21st century, however, direct current (DC) has made a resurgence to challenge AC, especially in behind-the-meter applications. DC power distribution in buildings has recently emerged as a path to improved efficiency, resilience, and cost savings in a transitioning building sector, thanks to three factors: (1) the increased market penetration and cost reductions of DC sources, such as photovoltaics (PV) [1] and battery storage [2]; (2) the availability of DC end uses, such as electronics, electric vehicles (EVs), and solid-state lighting [3]; and (3) recent advancements in power electronics technologies.

DC distribution in buildings with onsite DC sources powering DC end uses can lead to energy savings of up to 18 percent compared to AC distribution, according to power simulation studies [4-6] and field measurements [7,8]. Other studies have evaluated the potential cost savings from DC distribution, which can be realized through simpler 
power electronics, fewer power conversions, and the combination of communications and power distribution $[9,10]$. Furthermore, in buildings with DC distribution, onsite PV and electricity storage can provide resiliency benefits at a lower cost compared to equivalent AC systems [11,12]. Additional potential benefits of DC power distribution include fewer maintenance requirements, longer-lived system components, and simpler load control [13].

Despite these important benefits, the market for DC distribution in grid-connected buildings in the United States and globally is still in the demonstration phase, with few actual buildings utilizing DC directly from an onsite DC source to power building end uses (direct-DC). Although DC is used widely with Ethernet and Universal Serial Bus (USB), it is rarely linked to DC generation and storage. As previous studies have highlighted [14,15], several technological and market barriers impede the development of DC in buildings. First, the current electricity transmission system is based on AC, and each grid-connected building is supplied with AC power, requiring a conversion to DC for powering DC loads, when local DC generation (e.g., PV, storage) is not available. Other important barriers include the lack of a mature market for DC-ready equipment and converters; low technical and market awareness among practitioners; technological issues related to safety, grounding, and fault protection; and a lack of consensus on core technology standards. As mentioned above, the benefits of DC systems have been documented and quantified in some cases (e.g., efficiency). However, such benefits have mostly been evaluated individually or at the building level, and less often for specific applications, without considering real-world opportunities and challenges to implementation.

\section{Related Work}

Several studies have assessed the feasibility and potential benefits of DC in buildings for specific applications or end uses, typically through evaluation of experimental setups, modeling work, or a combination thereof. Such studies generally focus on specific system configurations (e.g., explicit voltage levels) and a single or limited set of metrics, with efficiency being the most prominent.

In data centers, DC distribution has been implemented successfully for more than a decade, and the associated efficiency benefits (approximately 5-7 percent energy savings [16]), reliability benefits [17], and improvements in power quality [18] have been studied extensively [19]. Several papers have also evaluated DC lighting for commercial buildings in particular, where solar generation is generally synchronous with lighting usage. Thomas et al. [20] conducted an economic analysis of DC systems in a commercial building and found a $5 \%$ reduction in levelized annual costs for direct-DC LED lighting systems compared to similar AC systems, while Frank et al. [21] estimated 6-8 percent energy savings for a direct-DC high bay lighting system without battery storage over an equivalent AC system. With regard to DC-powered air conditioning systems, Aguilar et al. [22] evaluated a hybrid (grid and solar-powered) heat pump and estimated a 74 percent reduction of carbon emissions at a 16 percent lower annualized system cost in comparison to a baseline, grid-powered air conditioning unit. Further, in a study on the use of DC microgrids for DC fast charging of EVs [23], the authors found that such configurations facilitate vehicle-togrid operations and integration with distributed energy resources (DERs). Finally, ref. [24] presented a framework for analyzing the effect of line voltage in residential DC distribution systems and highlights the importance of wire gauge, line voltage, and end-use loads for maximizing efficiency benefits in such systems.

Other studies have assessed how DC distribution can be applied in the building sector using a more qualitative approach, namely, by seeking expert feedback and recommendations. In 2014, a workshop with 50 attendees from various disciplines, was held in Sacramento, California, to identify opportunities, barriers, and future research directions to enable DC distribution in the built environment [25]. In 2016, a research study for the California Energy Commission solicited stakeholder input on DC power systems through a workshop of approximately 30 participants, electronic surveys with 39 respondents, and 10 detailed interviews with DC system researchers, designers, policymakers, and 
manufacturers [15]. Glasgo et al. [26] conducted telephonic interviews of 17 DC distribution experts and stakeholders to gain a better understanding of the greatest non-technical barriers to the deployment of DC systems. In another study, the United States National Electrical Manufacturers Association surveyed 39 participants (consisting primarily of equipment manufacturers) on the benefits, barriers, and recommendations for DC in buildings. Finally, Aloise-Young et al. [27] interviewed personnel in four commercial buildings in Colorado that had various levels of success with DC distribution, drawing conclusions from their experience and identifying a roadmap for successful implementation of DC distribution in buildings. Table 1 summarizes the main conclusions and recommendations of these studies.

Table 1. Summary of expert feedback on DC distribution systems.

\begin{tabular}{|c|c|c|}
\hline Study & Expert Feedback Method & Main Conclusions and Recommendations \\
\hline [25] & $\begin{array}{l}\text { - Workshop } \\
\text { (50 attendees) }\end{array}$ & $\begin{array}{l}\text { - Develop demonstration projects benchmarking best-in-class DC vs. } \\
\text { AC devices } \\
\text { - } \quad \text { Incorporate methodology that accounts for total cost of ownership } \\
\text { - A regulatory roadmap is needed to accelerate DC systems' implementation }\end{array}$ \\
\hline [15] & $\begin{array}{l}\text { - } \quad \text { Workshop } \\
\text { (39 attendees) } \\
\text { - Interviews } \\
\text { (10 participants) } \\
\text { - } \quad \text { Electronic surveys } \\
\text { (39 respondents) }\end{array}$ & $\begin{array}{l}\text { - } \quad \text { Conduct research and data on cost } \\
\text { - Deploy demonstration projects to validate performance, cost, and } \\
\text { raise awareness } \\
\text { - } \quad \text { vevelop protection standards and reach an agreement on DC } \\
\text { - Conduct research on power quality issues in DC vs. AC systems } \\
\text { Lack of DC devices is a major barrier }\end{array}$ \\
\hline [26] & $\begin{array}{l}\text { - } \quad \text { Interviews } \\
\text { (17 participants) }\end{array}$ & $\begin{array}{l}\text { - Greatest barriers are lack of awareness among professionals and lack of DC } \\
\text { devices and power system components } \\
\text { - Training programs for engineers and electricians could increase awareness } \\
\text { - Targeted use cases in which DC is clearly advantageous over AC could help } \\
\text { jumpstart the technology }\end{array}$ \\
\hline [28] & $\begin{array}{l}\text { - } \quad \text { Survey } \\
\text { (39 participants) }\end{array}$ & $\begin{array}{l}\text { - } \quad \text { Lack of DC products, standards, and pilot projects are major barriers } \\
\text { - } \quad \text { More communication and outreach are required } \\
\text { - } \quad \text { Outreach, policies, and standards are needed to encourage DC }\end{array}$ \\
\hline [27] & $\begin{array}{l}\text { - } \quad \text { Interviews } \\
\text { (8 participants) }\end{array}$ & $\begin{array}{l}\text { - The main technological barriers are the lack and incompatibility of DC } \\
\text { - System components } \\
\text { - } \quad \text { Duccessful installations require an owner willing to "champion" the project } \\
\text { bidding, and contracting are key aspects of successful projects }\end{array}$ \\
\hline
\end{tabular}

The goal of this paper is to define specific end-use cases for which DC in buildings is a value proposition today. To do so, we address technological and market readiness, efficiency, cost, and resiliency benefits, while also addressing challenges and offering recommendations for implementation. The study most relevant to this work was done by Pantano et al. [29]. That study discussed the motivation for DC distribution in buildings and the associated energy and non-energy benefits; it also identified a few demonstration projects and presented adoption pathways for DC distribution in residential buildings. This work, inspired by Pantano et al. [29], seeks to conduct a more comprehensive analysis to reach recommendations for DC adoption pathways. The current paper builds on that scope, and earlier work by a subset of the authors [30] and provides the following novel contributions:

- It expands the study scope beyond the residential sector to commercial buildings and communities. 
- It conducts a comprehensive technology and market assessment by evaluating DC standards and end-use devices (EUDs), analyzing field deployments of DC power distribution, and identifying DC products for electrical end uses in buildings.

- It utilizes the results of an expert elicitation of $20 \mathrm{DC}$ power and building professionals to outline opportunities, lessons learned, challenges, and specific applications for DC distribution systems in buildings.

- It conducts a simulation-based energy savings analysis of DC versus AC distribution for three end-use categories (EUCs): lighting, electronics, and motor-driven loads.

- It presents specific adoption pathways and evaluates each pathway's technological and market readiness, energy savings potential, and resiliency benefits.

This paper is organized as follows: Sections 2 and 3 present the technology and market assessments, respectively; Section 4 includes the efficiency analysis by end-use category; and Section 5 summarizes the results of the industry expert elicitation. Based on the findings of Sections 2-5, Section 6 presents the proposed adoption pathways for DC distribution, and finally, Section 7 concludes with a discussion and recommendations for future work.

\section{Technology Review}

\subsection{End-Use Devices}

DC has been available in telecommunications and certain niche markets (e.g., recreational vehicles, off-grid systems, marine applications) for decades. However, despite the gradual shift to more efficient DC-internal devices in grid-connected building applications (either electronics, solid-state lighting, brushless DC motors, variable frequency drives, or in combination), most electrical end uses in buildings today have an $\mathrm{AC}$ power input and include a rectifier, or power supply, to convert AC to DC [3,31,32]. In this paper, we group DC EUDs into the following categories: lighting, electronics, motor-driven equipment, and other DC-indifferent equipment, the latter encompassing EUDs not included under the first three categories, such as resistive loads. Here, we provide an overview of the role of DC in these categories:

- Solid-state lighting operates on DC. Light-emitting diodes (LEDs) are current-controlled devices that use a driver to regulate luminosity. DC LED drivers are typically more efficient and can be less expensive than AC LED drivers because they use fewer power electronics and do not need to rectify the AC input [10]. Specifically, DC drivers do not require large electrolytic capacitors for canceling AC power ripple [33,34]. Eliminating those capacitors can significantly increase the driver's life span. Furthermore, because DC voltage levels are generally better matched to the LED string voltage, DC drivers do not require an internal flyback transformer, which can lead to additional cost savings [35].

- Electronic equipment is the fastest growing electric load in the building sector and operates on DC. Desktop computers, televisions, and other display equipment generally include an internal rectifier that converts $120 \mathrm{~V}$ AC to the device's main DC bus voltage. Increasingly, several (primarily portable) electronics are also DC-ready; that is, they have a DC input and utilize an external power supply (also called power adaptor) to convert AC to DC. Cell phones, laptops, modems, and routers are examples of DC-ready electronics.

- Motor-driven equipment, such as fans, pumps, and refrigeration equipment, accounts for the largest electricity consumption in buildings in the United States. The most efficient equipment uses brushless DC motors and variable frequency drives where applicable [36]. These loads are DC-internal because they rectify the $60 \mathrm{~Hz}$ AC input to $\mathrm{DC}$, and use a separate inverter to drive the motor at the desired $\mathrm{AC}$ frequency. DC-powered variable frequency drives (VFD) avoid this rectification stage and utilize a smaller capacitor bus, leading to additional cost savings [31]. Even more efficient DC-internal motors, such as high-rotor pole switched reluctance motors and printed 
circuit board motors, are coming on the market, which could lead to additional energy and cost savings.

- $\quad$ Other DC-indifferent equipment includes items such as resistive heating elements. These are included in water heaters, cooking equipment (ovens, cooktops, toasters), hand irons, blow dryers, etc. Resistive elements are indifferent to DC or AC-they can be connected to AC or DC distribution without significant modifications.

\subsection{Distribution Standards}

AC distribution has little variation in most buildings, and AC voltages are generally standardized to specific categories. In contrast, DC can be deployed in a variety of ways, which differ in the topology of the wiring (e.g., radial, ring, ladder, or mesh bus architectures) and in whether the distribution system is managed. Managed DC technologies include communications for managing power distribution within a power cable [37]; examples include USB and Power over Ethernet (PoE).

For this paper, we consider two categories of DC voltage levels: "low" voltage (generally less than $60 \mathrm{~V}$ ) for powering loads less than $100 \mathrm{~W}$, which is consistent with National Electrical Code "Class 2" circuits and associated safety requirements, and "high" voltage (generally greater than $60 \mathrm{~V}$ and less than $1000 \mathrm{~V}$ ) for powering loads greater than $100 \mathrm{~W}$ and for longer wire lengths. Low voltage levels include USB (5-20 V), $12 \mathrm{~V}, 24 \mathrm{~V}$, and $48 \mathrm{~V}$. USB, $12 \mathrm{~V}$, and $24 \mathrm{~V}$ are typically used for powering low voltage electronics (e.g., hand-held devices, computers, monitors, and other office equipment), with USB-C input becoming more common. PoE and telecommunications also use $48 \mathrm{~V}$ and it is recommended for off-grid residential systems [38]. PoE has been a proven technology for nearly twenty years, but in the past decade, PoE applications and devices have increased due to higher allowable power levels at the end-use device (from $13 \mathrm{~W}$ in 2003 to $71 \mathrm{~W}$ in 2019), thanks to developing PoE standards [39]. As a result, PoE has gradually transitioned from being able to power a limited set of devices (e.g., telephones and security cameras) to being able to power LED lighting and, more recently, small appliances, laptops, TVs, and other smart building devices. On the high-voltage side, $380 \mathrm{~V}$ has been used in data centers in North America and has been standardized by the EMerge Alliance [40]. However, in Europe, China, and other countries, other distribution voltages have also been used and considered. Specifically in Europe, $350 \mathrm{~V}$ DC has been used in several deployments, in part because with bi-polar operation it can be doubled to $700 \mathrm{~V}$, while some deployments in China have used 375 V DC [41].

Overall, DC building distribution voltages are still evolving. Voltage standards may result in defining a range (e.g., 350-400 V) and specifying either common connectors, cabling requirements, or both, which are required for interoperability across end uses and power system components. For example, currently DC connectors are generally limited in the low-voltage range (with USB-C and PoE becoming increasingly common). However, there are still various DC coaxial power connectors (e.g., barrel connectors for portable electronics) that are incompatible with available DC sockets. For high-power, higher voltage applications, DC plugs and sockets are limited, with the exception of application-specific ones (e.g., for DC fast charging) and prototypes [42]. Such products have several challenges to overcome, such as arcing and load disconnection during active mode.

\section{Market Assessment}

\subsection{Deployment Case Studies}

This section evaluates DC distribution case studies in residential and commercial buildings in the United States and Canada. We focus on identifying DC end-use loads, DC applications, building types, and grid resiliency features at each site. Grid resiliency features include onsite energy generation (typically solar PV), battery storage, and ultimately, the ability to operate in island mode. While onsite solar PV and battery storage do not offer direct grid resiliency for buildings, they provide resiliency benefits by contributing to grid power demand reduction and potentially peak shaving. They are also prerequisites for 
buildings to operate in island mode (while onsite solar PV and battery storage do not offer direct grid resiliency for buildings, they provide resiliency benefits by contributing to grid power demand reduction and potentially peak shaving). They are also prerequisites for buildings to operate in island mode. The project team collected information on each deployment case study through site visits, phone interviews, and online research. Note that the following list of sites (presented in Figure 1 and Table 2) is not intended to be a comprehensive list, but rather a snapshot of the market, to provide information for the development of the proposed adoption pathways. Figure 1 shows a map of 21 sites identified by the authors, including the DC end uses at each location.

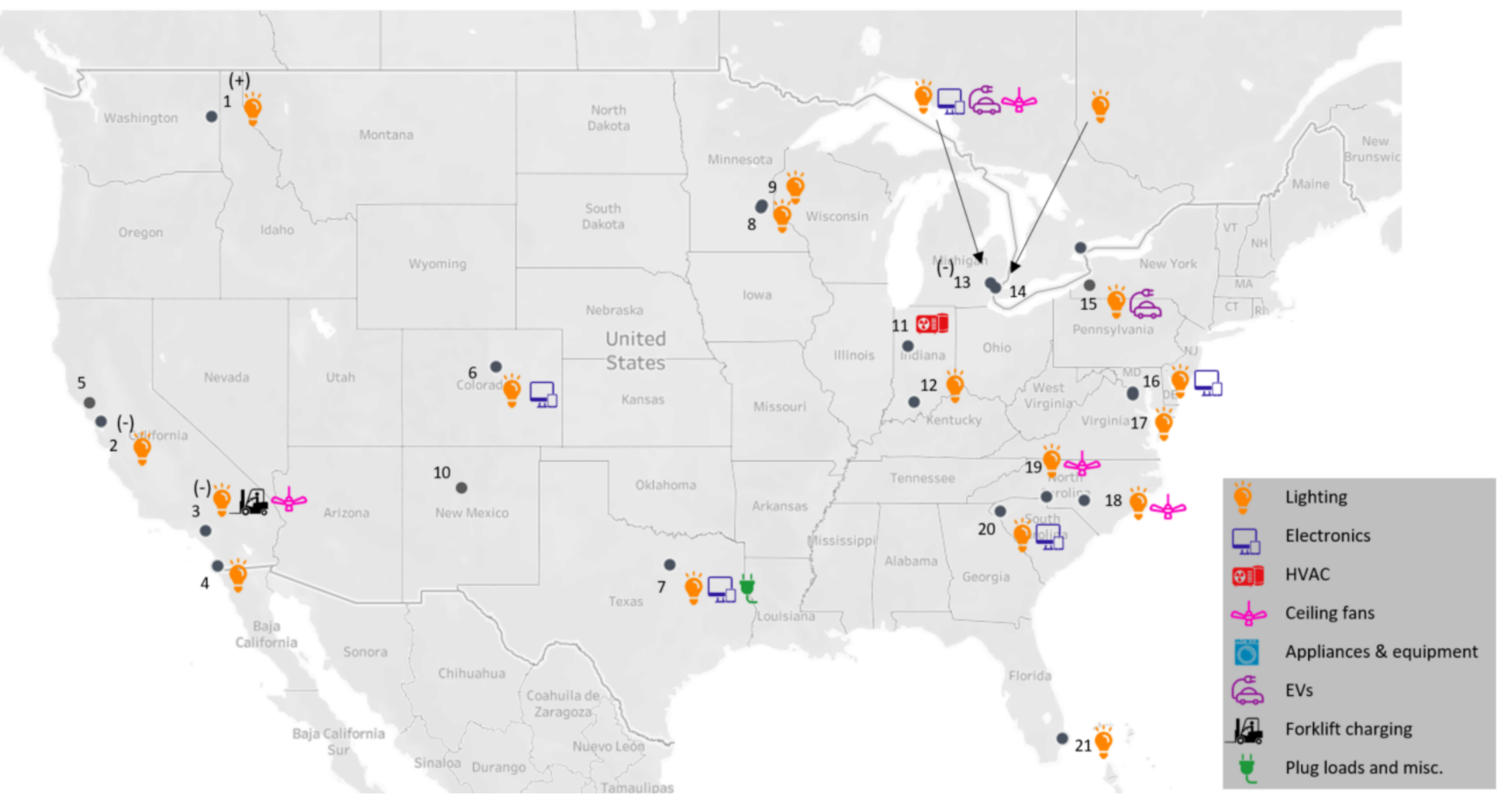

Figure 1. Map of DC distribution deployments in the United States and Canada. Note: Sites denoted with (-) are defunct/decommissioned; sites with (+) are in progress or the planning stage. Source: Lawrence Berkeley National Laboratory (map icons: thenounproject.com).

Table 2. Information on DC field deployments in the United States and Canada.

\begin{tabular}{|c|c|c|c|c|c|}
\hline$\#$ & Site and Location & Description & $\begin{array}{l}\text { Distribution } \\
\text { Voltage(s) }\end{array}$ & $\begin{array}{l}\text { Resiliency } \\
\text { Features * }\end{array}$ & $\begin{array}{l}\text { Information } \\
\text { Source } * *\end{array}$ \\
\hline 1 & Catalyst Building, Spokane, WA & $\begin{array}{l}\text { New zero-energy (ZE) building with } \\
\text { direct-DC lighting }\end{array}$ & Unknown & 疒- & URL \\
\hline 2 & Whole Foods Mkt., Berkeley, CA & $\begin{array}{l}\text { Supermarket retrofit with direct-DC } \\
\text { lighting system }\end{array}$ & $24 \mathrm{~V}$ & :ơ⿱宀八:- & URL \\
\hline 3 & Honda Distr. Center, Chino, CA & Warehouse retrofit (DC load: $175 \mathrm{~kW}$ ) & $380 \mathrm{~V}$ & -Ó- & I, URL \\
\hline 4 & $\begin{array}{l}\text { Sust. Resource Center, San } \\
\text { Diego, CA }\end{array}$ & $\begin{array}{l}\text { Demonstration of small direct-DC lighting } \\
\text { system (DC load: } 800 \mathrm{~W} \text { ) }\end{array}$ & $24 \mathrm{~V}$ & :ós'- & URL \\
\hline 5 & Silvercloud Winery, Glen Ellen, CA & $\begin{array}{l}\text { Microgrid connecting end uses, } \\
\text { generation, and battery storage }\end{array}$ & $380 \mathrm{~V}$ & - & URL \\
\hline 6 & Alliance Center, Denver, CO & $\begin{array}{l}\text { Proof of concept project in part of } \\
\text { commercial office building }\end{array}$ & $24 \mathrm{~V}, \mathrm{USB}$ & 准- & SV, I, URL \\
\hline 7 & Sinclair Hotel, Ft. Worth, TX & $\begin{array}{l}\text { 18-story hotel retrofit with PoE lighting } \\
(100 \%) \text {, electronics, and appliances }\end{array}$ & PoE & $\mathrm{N} / \mathrm{A}$ & SV, I, URL \\
\hline
\end{tabular}


Table 2. Cont.

\begin{tabular}{|c|c|c|c|c|c|}
\hline$\#$ & Site and Location & Description & $\begin{array}{l}\text { Distribution } \\
\text { Voltage(s) }\end{array}$ & $\begin{array}{l}\text { Resiliency } \\
\text { Features* }\end{array}$ & $\begin{array}{l}\text { Information } \\
\text { Source ** }\end{array}$ \\
\hline 8 & Public school, Edina, MN & $\begin{array}{l}\text { Retrofit of classroom and office room to } \\
\text { use PoE lighting (DC load: } 600 \mathrm{~W})\end{array}$ & PoE & $\mathrm{N} / \mathrm{A}$ & SV, I \\
\hline 9 & CEE building, Minneapolis, MN & $\begin{array}{l}\text { Partial cubicle area retrofit to } \\
\text { PoE-supplied lighting (DC load: } 480 \mathrm{~W} \text { ) }\end{array}$ & PoE & $\mathrm{N} / \mathrm{A}$ & SVI \\
\hline 10 & $\begin{array}{l}\text { Kirtland Airforce Base, } \\
\text { Albuquerque, NM }\end{array}$ & $\begin{array}{l}\text { Residential community microgrid using } \\
\text { DC bus to connect residences }\end{array}$ & $380 \mathrm{~V}, 750 \mathrm{~V}$ & -óe- & I, URL \\
\hline 11 & Purdue Univ., West Lafayette, IN & $\begin{array}{l}\text { Retrofit of an entire house for DC } \\
\text { distribution (demonstration) }\end{array}$ & $380 \mathrm{~V}$ & & I, URL \\
\hline 12 & $\begin{array}{l}\text { West Baden Springs Hotel, French } \\
\text { Lick, IN }\end{array}$ & $\begin{array}{l}\text { Retrofit of }>500 \text { light fixtures to PoE (DC } \\
\text { load: } 4 \mathrm{~kW})\end{array}$ & PoE & $\mathrm{N} / \mathrm{A}$ & URL \\
\hline 13 & Smart Home, Detroit, MI & $\begin{array}{l}\text { Residential test-bed for DC technologies } \\
\text { and appliances }\end{array}$ & USB, $24 \mathrm{~V}, 380 \mathrm{~V}$ & 象- & I, URL \\
\hline 14 & Bedrock Real Estate, Detroit, MI & $\begin{array}{l}\text { Retrofit of commercial office lighting } \\
\text { system }\end{array}$ & $24 \mathrm{~V}$ & $\mathrm{~N} / \mathrm{A}$ & URL \\
\hline 15 & $\begin{array}{l}\text { Burlington microgrid, } \\
\text { Burlington, CA }\end{array}$ & $\begin{array}{l}\text { Manufacturing facility building (DC } \\
\text { lighting load: } 12 \mathrm{~kW} \text { ) }\end{array}$ & $380 \mathrm{~V}$ & -Ò- & I, URL \\
\hline 16 & AGU Building, Washington, D.C. & $\begin{array}{l}\text { Six-story office building retrofit to ZE (all } \\
\text { lighting and offices powered by DC) }\end{array}$ & $24 \mathrm{~V}, \mathrm{USB}, 48 \mathrm{~V}$ & - & SV, I, URL \\
\hline 17 & Fort Belvoir, Alexandria, VA & $\begin{array}{l}\text { Partial demonstration fluorescent lighting } \\
\text { system retrofit (DC load: } 1 \mathrm{~kW} \text { ) }\end{array}$ & $24 \mathrm{~V}$ & 家- & URL \\
\hline 18 & Fitness center, Fort Bragg, NC & $\begin{array}{l}\text { Retrofit of } 44 \text { lighting fixtures, } 4 \text { ceiling } \\
\text { fans (DC load: } 15 \mathrm{~kW})\end{array}$ & $380 \mathrm{~V}$ & -'ó- & I, URL \\
\hline 19 & $\begin{array}{l}\text { Livingston and Haven, } \\
\text { Charlotte, NC }\end{array}$ & $\begin{array}{l}25,000 \mathrm{ft}^{2} \text { facility retrofit with high bay } \\
\text { lights and ceiling fans (DC load: } 15 \mathrm{~kW} \text { ) }\end{array}$ & $380 \mathrm{~V}, 48 \mathrm{~V}$ & - & SV, I, URL \\
\hline 20 & Watt Center, Clemson, SC & $\begin{array}{l}\text { Partial retrofit to showcase PoE lighting } \\
\text { and electronics (DC load: 5-10 kW) }\end{array}$ & PoE & $\mathrm{N} / \mathrm{A}$ & SV, I, URL \\
\hline 21 & PNC Bank, Fort Lauderdale, FL & $\begin{array}{l}\text { ZE building with partial DC lighting } \\
\text { system }\end{array}$ & $24 \mathrm{~V}$ & 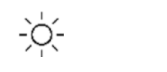 & URL \\
\hline
\end{tabular}

* Resiliency features: mode. ${ }^{* *}$ Info source: SV = site visit by the authors; I = phone or face-to-face interview; URL = online research.

Table 2 provides additional information for each site shown in Figure 1. It includes the name and location of each site, a brief description of the DC distribution system, the distribution voltage or voltages used to supply power to the end uses, the resiliency features of each site, and the source of information for each site (details on the field deployments, contacts, and information sources for each site are available upon request).

\subsection{Availability of DC End Uses}

As discussed in the introduction, the lack of availability of DC appliances and DC system power converters is a key barrier for DC distribution systems. Table 3 summarizes the state of the DC appliance market in the United States for various device groups found in residential and commercial buildings. We utilize our findings from the field deployment assessment (Section 3.1), as well as the results of our market survey of available products, to identify market gaps, challenges, and opportunities. As shown in Table 3, there is a direct correlation between the DC devices that are available for sale in the market and their corresponding presence in field deployments. In certain instances, field deployments have used (or plan to use) prototypes of DC appliances that are not available for sale, but rather are custom-made by manufacturers or retrofitted to have a DC input. 
Table 3. Availability of DC-ready devices.

\begin{tabular}{|c|c|c|c|c|c|}
\hline Device Groups & Device Subgroups & $\begin{array}{l}\text { "Standard" DC } \\
\text { Voltages }\end{array}$ & $\begin{array}{l}\text { Sites } \\
\text { Avail. }\end{array}$ & $\begin{array}{l}\text { Market } \\
\text { Avail. }\end{array}$ & Availability Comments \\
\hline Electronics & $\begin{array}{l}\text { TVs, cell phones, } \\
\text { printers, and scanners; } \\
\text { audio, network, and } \\
\text { computing equipment }\end{array}$ & $\begin{array}{l}\text { PoE, USB, } \\
12 \mathrm{~V}, 24 \mathrm{~V}\end{array}$ & th & 蚁识 & $\begin{array}{l}\text { - } \quad \text { Electronics are DC-internal but there is limited } \\
\text { availability of DC-ready products } \\
\text { - } \quad \text { Input voltages vary. USB/USB-C input } \\
\text { becoming more common. PoE input is } \\
\text { also available. }\end{array}$ \\
\hline Lighting & $\begin{array}{l}\text { General, landscape, } \\
\text { high bay, and task } \\
\text { lighting }\end{array}$ & $\begin{array}{l}\text { PoE, } 12 \mathrm{~V}, \\
24 \mathrm{~V}, 48 \mathrm{~V}, 380 \mathrm{~V}\end{array}$ & 故故故 & t战 & 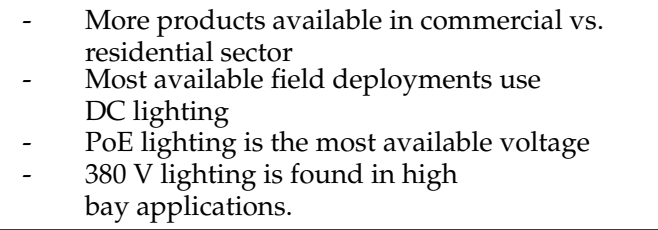 \\
\hline Refrigeration & $\begin{array}{l}\text { Refrigerators, freezers, } \\
\text { ice makers, vending } \\
\text { machines }\end{array}$ & $\begin{array}{l}\text { PoE, } 12 \mathrm{~V}, \\
24 \mathrm{~V}, 380 \mathrm{~V}\end{array}$ & th & $\star$ & $\begin{array}{l}\text { - Most available products used in the } \\
\text { off-grid market } \\
\text { - } \quad \text { High-voltage prototypes currently tested by } \\
\text { major appliance manufacturers. }\end{array}$ \\
\hline $\begin{array}{l}\text { Space heating } \\
\text { and cooling }\end{array}$ & $\begin{array}{l}\text { Heat pump/rooftop air } \\
\text { conditioners, variable } \\
\text { refrigerant flow units, } \\
\text { portable and ceiling } \\
\text { fans, radiant floor } \\
\text { heating }\end{array}$ & $12 \mathrm{~V}, 24 \mathrm{~V}, 380 \mathrm{~V}$ & t & t & $\begin{array}{l}\text { - } \quad \text { Small capacity }(\leq 18,000 \text { BTU) units available } \\
\text { for off-grid applications } \\
\text { - } \quad \text { Retrofitted ceiling fans for high bay } \\
\text { applications are available in field deployments } \\
\text { - } \quad \text { Major manufacturers have tested DC } \\
\text { HVAC systems. }\end{array}$ \\
\hline Cooking & $\begin{array}{l}\text { Induction cooking, } \\
\text { microwave ovens }\end{array}$ & $12 \mathrm{~V}, 380 \mathrm{~V}$ & $\varnothing$ & $\star \star$ & $\begin{array}{l}\text { - } \quad \text { Some products available for mobile } \\
\text { applications (12 V microwaves) } \\
\text { - } \quad \text { Induction stoves and microwaves can be } \\
\text { DC-powered. }\end{array}$ \\
\hline Water heating & $\begin{array}{l}\text { Heat pump water } \\
\text { heaters }\end{array}$ & $380 \mathrm{~V}$ & $\varnothing$ & $\varnothing$ & $\begin{array}{l}\text { - Heat pump water heaters could be coupled } \\
\text { with PV. }\end{array}$ \\
\hline $\begin{array}{l}\text { Large appliances } \\
\text { and other motor } \\
\text { loads }\end{array}$ & $\begin{array}{l}\text { Clothes washers and } \\
\text { driers, dishwashers, } \\
\text { pumps, fans, } \\
\text { compressors }\end{array}$ & $380 \mathrm{~V}$ & 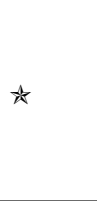 & t & $\begin{array}{l}\text { - } \\
\text { (AC and DC) input have been tested by } \\
\text { manufacturers } \\
\text { - } \quad \text { Motor drives could be adapted to use a variety } \\
\text { of DC input voltages. Retrofits may require } \\
\text { Underwriters Laboratories (UL) certification. }\end{array}$ \\
\hline EV charging & $\begin{array}{l}\text { DC fast charging } \\
\text { equipment }\end{array}$ & $380 \mathrm{~V}$ & 故 & $\star \star$ & $\begin{array}{l}\text { - } \quad \text { Some companies are beginning to offer } \\
\text { direct-DC charging equipment } \\
\text { - } \quad \text { Available sites have used custom DC chargers. }\end{array}$ \\
\hline $\begin{array}{l}\text { Miscellaneous } \\
\text { loads }\end{array}$ & $\begin{array}{l}\text { Vacuum cleaners, } \\
\text { humidifiers, garage } \\
\text { doors, hairdryers, irons, } \\
\text { window shades, } \\
\text { process loads }\end{array}$ & $\begin{array}{l}\text { PoE, USB, } 12 \mathrm{~V}, \\
24 \mathrm{~V}, 48 \mathrm{~V}, 380 \mathrm{~V}\end{array}$ & $\star$ & t & $\begin{array}{l}\text { - } \quad \text { Low power loads (timers, motor controls, } \\
\text { window shades) are available with PoE } \\
\text { - } \\
\text { Higher power loads can be powered with } \\
\text { high-voltage }(380 \mathrm{~V}) \text { or battery-assisted } \\
\text { lower voltage. }\end{array}$ \\
\hline
\end{tabular}

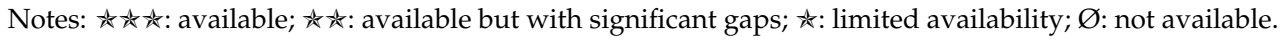

\section{Energy Savings by End-Use Category}

In 2017, a subset of the authors of this paper conducted a simulation-based efficiency comparison between the AC and DC distribution systems in modeled commercial buildings [4]. For this study, we conducted a similar analysis with the same analytical framework, but we focused on the savings of specific EUCs: electronics, lighting, and motor-driven loads. Two commercial buildings were analyzed using building dimensions and load profiles from the United States Department of Energy's EnergyPlus reference buildings [43]. These buildings are a medium office building $\left(\sim 5000 \mathrm{~m}^{2}\right.$ floor area, 3 stories $)$ and a mid-rise apartment building ( $\sim 3000 \mathrm{~m}^{2}$ floor area, 4 stories). They were selected to reflect the building types likely to adopt DC distribution systems and to include a range of load profiles that bracket the range of the loads' coincidence with PV generation.

Because the most efficient appliances are natively DC (i.e., they either have a DC input or use an internal DC stage) [3], to estimate the technical potential benefit of DC distribution, all-electric EUDs within the selected buildings were assumed to operate 
internally on DC. For the AC distribution system, this meant that all end uses required a load-packaged rectifier that converts AC to DC. For the DC distribution system, however, the loads were assumed to be designed optimally, such that their internal DC voltage matched the building distribution voltage. Three distribution system configurations were assessed for each building: a conventional grid-connected system without $\mathrm{PV}$, a system with onsite PV, and a system with onsite PV and battery storage. In addition, to account for the potential effects of climate, the efficiency model was run in three cities representing the range of solar irradiance in the contiguous United States: Miami (hot), San Francisco (mild), and Duluth (cold) for ASHRAE climate zones 1A, 3C, and 7, respectively. In sum, the comparison of DC versus AC distribution was examined for a combination of two types of commercial buildings, three distribution system configurations, three climate regions in the United States, and three EUCs, as presented in Figure 2.
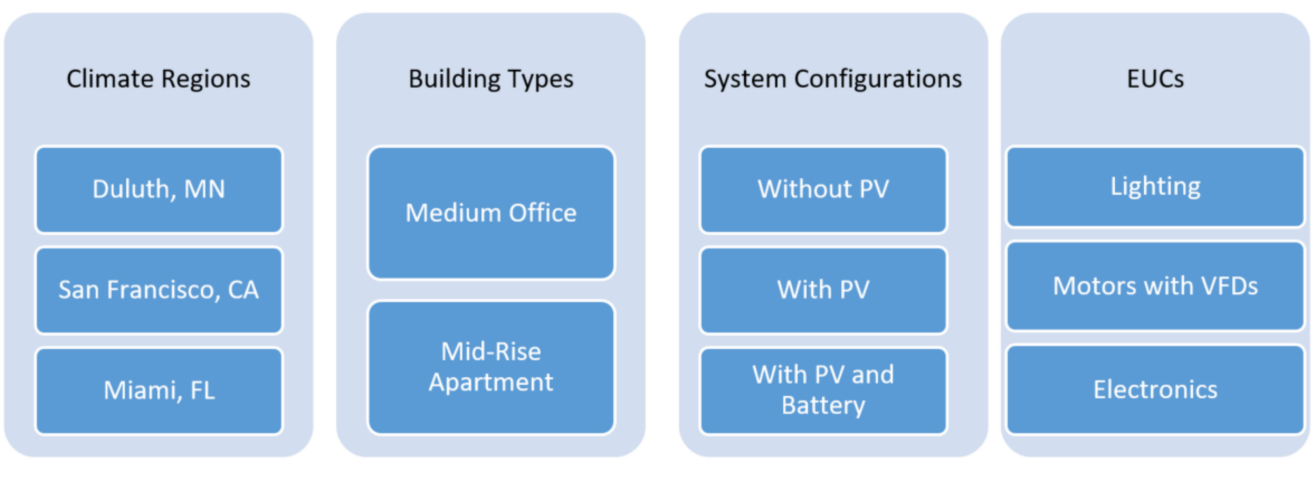

Figure 2. Summary of DC vs. AC distribution system efficiency comparisons.

The AC and DC building distribution systems were simulated in Modelica, a software used for building modeling of complex systems that include electrical, thermal, mechanical, control, or other process-oriented components. The building simulation model includes several electrical sources and loads, including the connection to the electric grid, EUCs, and PV generation and batteries, where available. Electrical losses are attributed to converters, building distribution wiring, and chemical losses in the battery. The electrical end uses in the AC and DC building are identical (except for the load-packaged rectifiers in the AC building), and they have the same layout and usage profiles.

PV generation data for each building in each climate zone were derived from PVWatts [44]. The capacity of the PV system (in kilowatts) for each load category was set such that the total energy consumed by the load was equal to the solar generation of the PV array on an annual basis. The battery capacity (in kilowatt-hours) was set to $50 \%$ of the amount required to store all excess solar generation on the sunniest day of the year. Furthermore, all converters were oversized by $125 \%$ of the peak power to the connected load, which is a typical oversize factor [10]. Converter efficiency curves were derived from actual market data. For each converter in the model, the median efficiency curve (from a series of efficiency curve sets) was used. The simulation model, inputs, and assumptions for each component are discussed in more detail in Gerber et al. [4]. For details on the converter efficiency curves, see Appendix E of that study.

The novelty in this analysis approach is that to estimate savings for each EUC, we ran the model for each EUC separately (unlike the analysis described in Gerber et al. [4]) by removing all other EUCs for each run, and sizing the power system components only for the considered EUC. This approach yields EUC-specific estimates of percent energy savings achievable by the use of DC distribution. However, this analysis does not address power quality and the effects on harmonics on the overall system efficiency, which are addressed in $[45,46]$. Table 4 shows the efficiency savings from DC distribution for each EUC and system configuration, averaged over all climate zones and building types. 
Table 4. DC distribution efficiency improvement by EUC and system configuration.

\begin{tabular}{cccc}
\hline \multirow{2}{*}{ EUC } & \multicolumn{3}{c}{ DC Distribution Efficiency Improvement (\%) } \\
\cline { 2 - 4 } & No PV & PV & PV and Battery \\
\hline Electronics & $5.8 \%$ & $8.3 \%$ & $14.9 \%$ \\
LED Lighting & $3.1 \%$ & $5.1 \%$ & $13.0 \%$ \\
Motor-Driven Loads & $7.4 \%$ & $10.3 \%$ & $15.2 \%$ \\
\hline
\end{tabular}

Similar to the findings in Vossos et al. [47], our results vary only slightly across the three modeled cities. Given that the PV system in each city is sized such that its generation matches the corresponding EUC's annual energy consumption, this result is not surprising. However, in practice, in locations with a lower solar irradiance, there may be constraints in PV array sizing, such as limited rooftop area or higher cost per kilowatt installed. The office building generally produced higher savings compared to the mid-rise apartment, with increases in savings ranging between $0.1 \%$ and $1.5 \%$. This is primarily due to the better coincidence of load and PV generation in the office building. Regarding system configuration, as shown in Table 4, the most savings occur when most DC power generated locally is consumed by DC loads (even more so via a battery) and when most power for DC loads comes from DC generation. Systems with PV and battery storage had the highest savings because of fewer AC-DC and DC-AC conversions in the DC distribution system compared to the corresponding AC configuration. Overall, systems with battery storage utilized less grid power; therefore, the DC distribution system used less rectified AC power for distribution in the building. We also note that, although we did not explicitly model system efficiency for weekdays versus weekends (the latter typically corresponding to less end-use consumption due to low occupancy), as shown in Frank et al. [21], we expect lower overall DC efficiency gains during weekends due to general lack of coincidence of load and PV generation. The results shown in Table 4 reflect the weighted-average savings resulting from the building's load profiles during a one-year period. Finally, when comparing savings by EUC, motor-driven loads yielded the highest savings, followed by electronics, and, lastly, LED lighting. The main drivers for EUC savings are-as discussed earlier-coincidence of load and PV generation (which, evidently, is lower for lighting), and the efficiencies of load-packaged rectifiers in the AC system compared to DC-DC converters in the DC system.

\section{Expert Elicitation}

The project team conducted interviews with various industry stakeholders (roughly equally split among electrical designers, contractors, tradespeople, building owners/managers, DC equipment integrators, manufacturers, and academics) to collect information on their experience with DC distribution, and to solicit feedback on opportunities, challenges, and recommendations for DC distribution in buildings. These interviews were also instrumental in identifying accurate and detailed field deployment information, which we presented in Section 3. Overall, the project team conducted 20 in-depth interviews, by phone or faceto-face during site visits. Table 5 summarizes the notable findings from these interviews. Similar to the rest of this paper, we correlate interviewees' feedback by EUC, and rank their observations by the number of occurrences (i.e., the number of interviewees making a similar point). 
Table 5. Summary of expert elicitation feedback.

\begin{tabular}{|c|c|c|c|c|c|c|}
\hline Topic Area & Interviewees' Feedback & 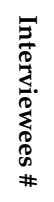 & 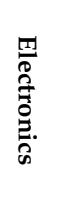 & 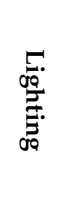 & 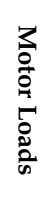 & 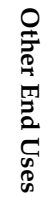 \\
\hline \multirow{3}{*}{ Opportunities } & \multirow{3}{*}{$\begin{array}{l}\text { Low-voltage DC/PoE has reduced installation cost-no licensed electricians required } \\
\text { Low-voltage DC / PoE is reconfigurable (e.g., allows moving electrical outlets without worry of } \\
\text { electrical shock) } \\
\text { PoE allows control of energy consumption on all switch ports }\end{array}$} & 3 & $\checkmark$ & $\checkmark$ & & $\checkmark$ \\
\hline & & 2 & $\checkmark$ & $\checkmark$ & & $\checkmark$ \\
\hline & & 1 & $\checkmark$ & $\checkmark$ & & $\checkmark$ \\
\hline \multirow{5}{*}{ Challenges } & \multirow{5}{*}{$\begin{array}{c}\text { Misconception and lack of knowledge leads to lengthy/expensive design and permit process } \\
\text { DC metering and robust connector standards are currently unavailable } \\
\text { Small companies providing DC technologies are risky (several have gone out of business) } \\
\text { DC microgrid control systems are expensive and proprietary; no plug-and-play } \\
\text { product available } \\
\text { PoE switch cannot be fully turned off (security issues, standby losses) }\end{array}$} & 5 & $\checkmark$ & $\checkmark$ & $\checkmark$ & $\checkmark$ \\
\hline & & 3 & $\checkmark$ & $\checkmark$ & $\checkmark$ & $s$ \\
\hline & & & & & & \\
\hline & & 2 & $\checkmark$ & $\checkmark$ & $\checkmark$ & $\checkmark$ \\
\hline & & 1 & $\checkmark$ & $\checkmark$ & & $\checkmark$ \\
\hline \multirow{4}{*}{ Recommendations } & $\begin{array}{l}\begin{array}{c}\text { Big companies should be involved to avoid bankruptcy risk, along with a small number of } \\
\text { vendors for efficiency }\end{array}\end{array}$ & 4 & $\checkmark$ & $\checkmark$ & $\checkmark$ & $\checkmark$ \\
\hline & $\begin{array}{l}\text { Permitting authorities must be involved early in projects } \\
\text { DC }\end{array}$ & 3 & 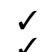 & 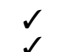 & 3 & 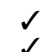 \\
\hline & $\begin{array}{l}\text { DC system vendors should offer a package of DC end uses to consumers } \\
\text { Dual-input devices would be compatible with both AC and DC distribution }\end{array}$ & $\begin{array}{l}3 \\
2\end{array}$ & $\checkmark$ & $\checkmark$ & $\checkmark$ & $\sqrt{3}$ \\
\hline & Spot inverters can be used for specialized devices without DC input & 1 & & & & $\checkmark$ \\
\hline \multirow{5}{*}{$\begin{array}{l}\text { Suggested } \\
\text { applications and } \\
\text { adoption } \\
\text { pathways }\end{array}$} & Community microgrids of multiple buildings & 3 & $\checkmark$ & $\checkmark$ & $\checkmark$ & $\checkmark$ \\
\hline & Lighting applications in commercial buildings & 3 & & $\checkmark$ & & \\
\hline & EV charging for commercial applications & 2 & & & & $\checkmark$ \\
\hline & Electronics and office equipment & 2 & $\checkmark$ & & & \\
\hline & $\begin{array}{l}\text { Big box buildings with warehouse and office space } \\
\text { All-DC buildings, due to efficiency benefits }\end{array}$ & $\begin{array}{l}1 \\
1\end{array}$ & 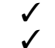 & 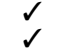 & 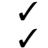 & 1 \\
\hline
\end{tabular}

Note: For each topic area, the table presents feedback by interviewees, the number of interviewees that provided said feedback, and the end uses for which the feedback is applicable.

\section{Installation Cost Savings}

The top-cited opportunity in Table 5 is the reduced installation cost of low-voltage DC/PoE because it does not require licensed electricians for the installation. This was also the top-cited benefit of DC lighting in a recent study evaluating DC lighting and microgrids [48]. Manufacturers and vendors of these technologies frequently market this benefit when selling the technology; however, it has not been independently verified and may not be realized in many jurisdictions. Although low-voltage DC/PoE is a safer technology and is treated differently by the National Electric Code as Class 2 or Class 3 wiring, many states, counties, and municipalities require it to be installed by fully licensed electricians.

As shown in Figure 3, as of 2015, 20 states required an electrician license to install low-voltage wiring. A further ten states required some form of specialty low-voltage license, and only 21 states did not have any statewide licensing requirements for low-voltage. However, cities or counties without statewide requirements may require a licensed electrician for low-voltage DC distribution systems, especially in jurisdictions with established permitting processes and infrastructure. Furthermore, low-voltage DC may fall into an area of uncertainty for licensing requirements. Historically, low-voltage wiring has been associated primarily with fire alarm, signaling, and telecommunications systems, not with powering building systems, such as lighting. Thus, many regulations do not require a full electrician license for low-voltage wiring but do require a full license to install any wiring to power lighting. Local authorities with jurisdiction may interpret the code with the more stringent requirement, such that all power wiring for lighting must be installed by an electrician, regardless of whether it is low voltage. 


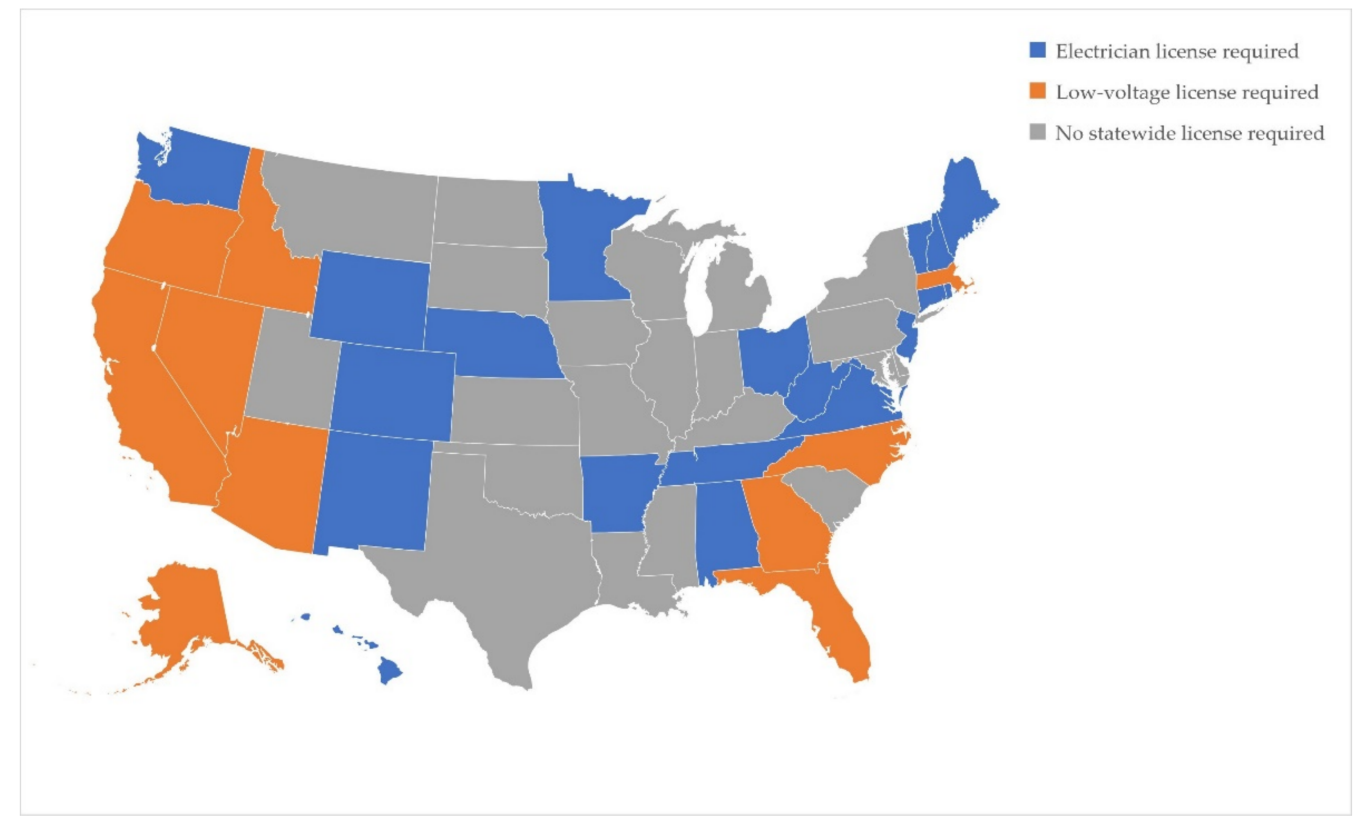

Figure 3. Statewide electrical licensing requirements for installation of low-voltage lighting. Source: [44].

\section{Adoption Pathways}

This section utilizes the findings discussed in Sections 2-5 and summarizes proposed adoption pathways of DC power in buildings. Each pathway includes a discussion of motivation, potential benefits, challenges, and technical issues arising from its deployment. It is important to note that these adoption pathways are not mutually exclusive. We present applications for DC that are viable today and have high growth potential but limited if any, current market penetration. For this reason, technologies and applications that are past the infancy stage and are currently generally considered viable for DC distribution (e.g., DC in data centers), are not presented in this paper.

\subsection{Office Workstations}

Contemporary office electrical loads are dominated by electronics: computers, monitors, desk phones, and charging for mobile devices. Other common loads are lighting, portable fans, and, in some buildings, space heaters. All of these are amenable to DC powering; with short distances, USB is a viable choice, able to provide up to $100 \mathrm{~W}$. In an existing ZE installation, building designers mentioned that the $100 \mathrm{~W}$ power limit was a key element for controlling occupant energy use, because it limited the use of high-power devices such as resistance space heaters. This pathway is most valuable when it skips AC power distribution to workstations entirely. Workstation loads have high value to users; therefore, ensuring that their power delivery is reliable—backed by a battery-can be important. That same battery can also be used to time-shift PV power. Managed DC can prioritize loads if power is short and can keep the total load under capacity limits.

This pathway avoids AC distribution to workstations entirely, thus having the potential for cost reductions while increasing efficiency and reliability. DC outlets and cables are also less bulky than their AC counterparts. Two distinct cases are individual workstations (as in conventional offices) and clusters of two, four, or more workstations that are contiguous and so could have a common infrastructure. While mobile and desktop computers and phones can use Wi-Fi for communications, having Ethernet as an option can be advantageous. Ethernet could be used as the power delivery mechanism to a workstation, providing the needed communication pathways. Single Pair Ethernet, which uses two cables that deliver up to $50 \mathrm{~W}$ each, could be preferable for this purpose, primarily due to its small size and low cost [49]. If more power is needed than a single Ethernet cable can 
provide, then multiple cables can be placed in parallel. This could be implemented via a hub that takes in Ethernet and outputs various forms of USB as well as Ethernet, for both data and power.

A key prerequisite for this pathway is the availability of DC-powered devices. Many DC-powered devices are available today (PCs, monitors, phones, task lights), but having a greater variety would be helpful. As shown in Table 3, all electronic devices are DCinternal but there is limited availability of DC-ready products. This will require better standardization and consolidation of the various low-voltage connectors to one or two types that can accommodate most workstation voltage and power levels. In addition, a long-distance link technology is needed to supply power to workstation hubs; this could be a 380 V DC bus with a step-down converter that could power low-power loads locally. Basic mechanisms for prioritization and power allocation are also needed; these can build on capabilities already present in USB and Ethernet. For systems with multiple parallel stepdown converters, an efficiency optimization algorithm that regulates current between the converters could be used to optimize the system efficiency [50]. See Figure 4 for a conceptual schematic of this proposed configuration. For open office spaces, bringing power down from the ceiling or up from the underfloor to a collection of adjacent workstations can be convenient. While cost savings can occur in any building, energy savings will generally rely on being coupled to PV (with or without battery storage); therefore, installation should be tied to either a general retrofit, PV installation, or in combination.

\section{V DC}

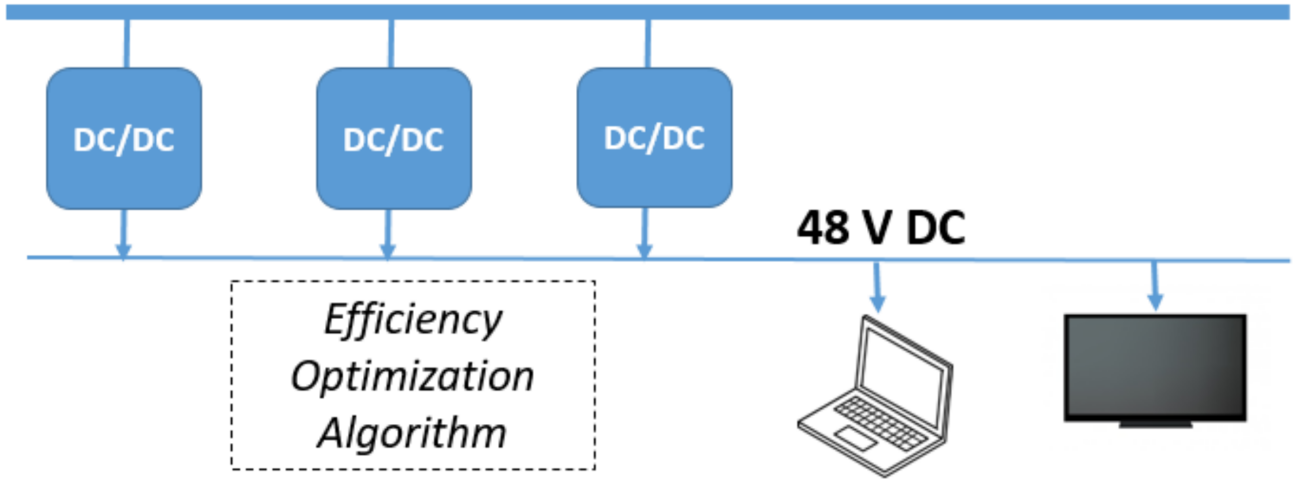

Figure 4. Example of DC-powered PoE lighting system.

\subsection{PoE Lighting}

PoE lighting uses category 5/6/7 Ethernet cables to both provide DC power and enable network communication with lighting fixtures, sensors, and devices. As discussed in Section 2.2, the availability of PoE EUDs has grown quickly during the past decade. For lighting specifically, a recent study identified more than 17 lighting manufacturers who offered the technology in a wide range of lighting fixtures [48]. Beyond lighting, PoE is expected to grow as other devices and building loads adopt it for power and data exchange. PoE utilizes the TCP/IP protocol, making it well suited for smart buildings that require integration and data exchange between building systems and devices.

This pathway would target an established DC technology and apply it to lighting. PoE lighting availability and adoption are growing quickly. Its potential benefits extend beyond energy efficiency, also including lower deployment costs, simplified installation, flexibility, integration with other systems, and improved reliability. The network management software allows power draw monitoring at each port and managing the power that can be drawn. PoE systems have the inherent capability to measure their energy usage, which can be leveraged for energy optimization and management. An additional benefit is that PoE is already standardized and established for phones and security systems, and therefore a supply chain and qualified workforce to install PoE systems already exists. Reconfigurability may become another driving factor, as single touch-safe cables and devices can be installed 
in spaces where no AC outlets may be accessible. Non-electricians, such as IT personnel or staff, can reconfigure PoE lighting fixtures or other devices as needed to adapt to the changing needs of the space. Figure 5 shows an example direct-DC PoE lighting system.

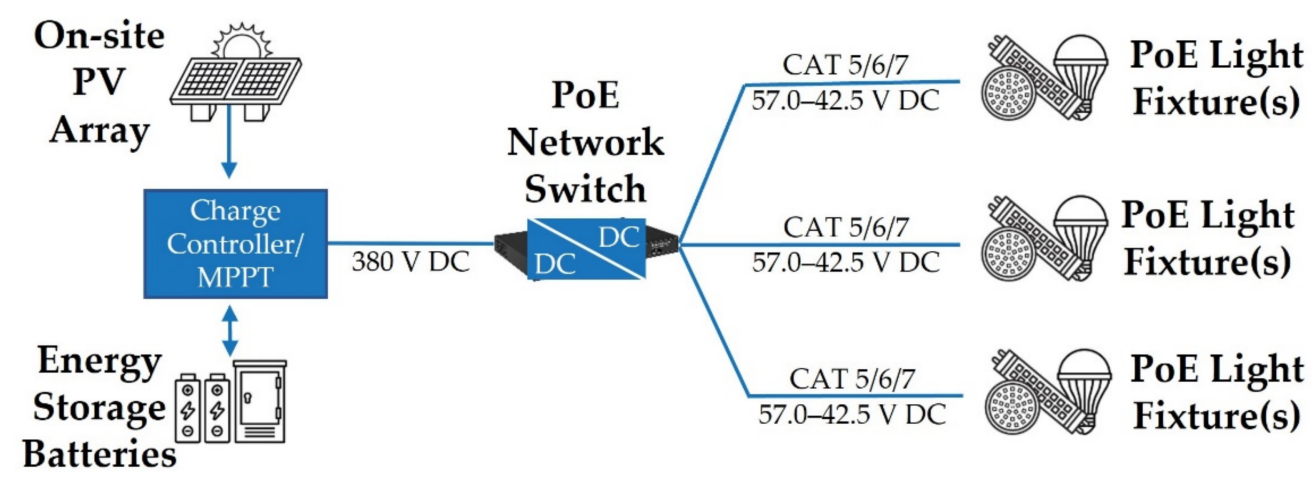

Figure 5. DC-powered PoE lighting system.

Current POE lighting systems may not be as energy-efficient as traditional AC lighting systems in some applications, due to power losses in CAT 5/6/7 cabling and standby power losses in PoE switches [51]. Standards, distributed architectures, and larger gauge cables are available to reduce cable losses; however, more work is needed to deploy these practices in the market. PoE switches need improvements to reduce losses, especially in no-load and dimmed conditions for lighting. An additional challenge is that there are no PoE switches available that accept DC power at the input, so an inverter is required to connect PoE lighting to PV panels and energy storage batteries. Should PoE switches be able to accept DC, lighting could be powered directly from PV and battery storage, which would offer additional energy savings, grid, and reliability benefits. PoE is limited to $100 \mathrm{~m}$ of cabling from the network switch to each end-use device. Longer runs are possible through PoE power injectors, which effectively remove the need to have an additional network switch at longer distances, with the caveat that they can cause energy losses. PoE systems allow for IP-addressable devices with high visibility, controllability, and permit integration with other building systems (e.g., alarm systems) present on the network. PoE systems also require the use of hardware and software, especially related to the IT network. Software and firmware updates must maintain compatibility among all the system components to operate properly; this is critical during installation and maintenance.

\subsection{EV Charging}

In this pathway, DC-input electric vehicle service equipment (EVSE) replaces traditional, AC-input level 2 or AC-input DC fast chargers, allowing for more flexible and efficient EV charging. DC-input chargers still follow existing DC fast charger interconnection standards (e.g., CHAdeMO, CCS), but the EVSE input is fed by a DC bus rather than a 3-phase AC system. EVSE power levels can be flexible, ranging from typical AC level 2 $(6.6 \mathrm{~kW})$ to DC ultra-fast charger power levels $(200+\mathrm{kW})$, depending on the device ratings. The EV's onboard rectifier (AC/DC converter) power rating is no longer a constraint.

DC EV charging is most appropriate for EVSE coupled with PV systems via a DC link. This reduces complexity, eliminates the need for inverters and grid synchronization, and increases efficiency. This is especially true when battery storage is also used-for instance, to mitigate peak demand events from DC fast charging, which can be beneficial from the utility's perspective (for reliability reasons) or the customer's perspective (for economic reasons). DC EV charging can be grid-connected (in which grid power supplements power from either PV, battery storage, or both) or grid-independent (in which the entire system is self-contained to reduce utility demand charges). As discussed in earlier studies [15,52], EV charging is most beneficial in applications where EV charging and local PV generation are coincident. Such applications may include commercial parking spaces with onsite PV canopies (e.g., company parking garages, electric school bus depots), and residential solar 
community systems. For such applications, fleet management software may be appropriate for regulating vehicle and battery charging and usage based on current and expected PV generation.

DC-coupled EVSEs can also offer resiliency features by charging critical vehicles from $\mathrm{PV}$ or battery storage without requiring an AC microgrid (and its associated complexity). The power electronics, including communications and control components, of DC-input EVSEs would require minor modifications, resulting in simpler hardware and control schemes. Even though DC-input EVSEs are still at the demonstration phase, at scale, DCcoupled chargers would have fewer components and cost less than their AC counterparts. The estimated 2-3\% efficiency gain from DC/DC (versus AC/DC) conversion (which is estimated to be higher for systems with battery storage) translates directly to reduced cost for companies selling charging services, making them more competitive. See Figure 6 for a conceptual schematic of the above configurations. According to our technology and market assessment, there is a limited number of companies offering DC-input chargers, while two existing sites have installed or plan to install DC-input EVSE.

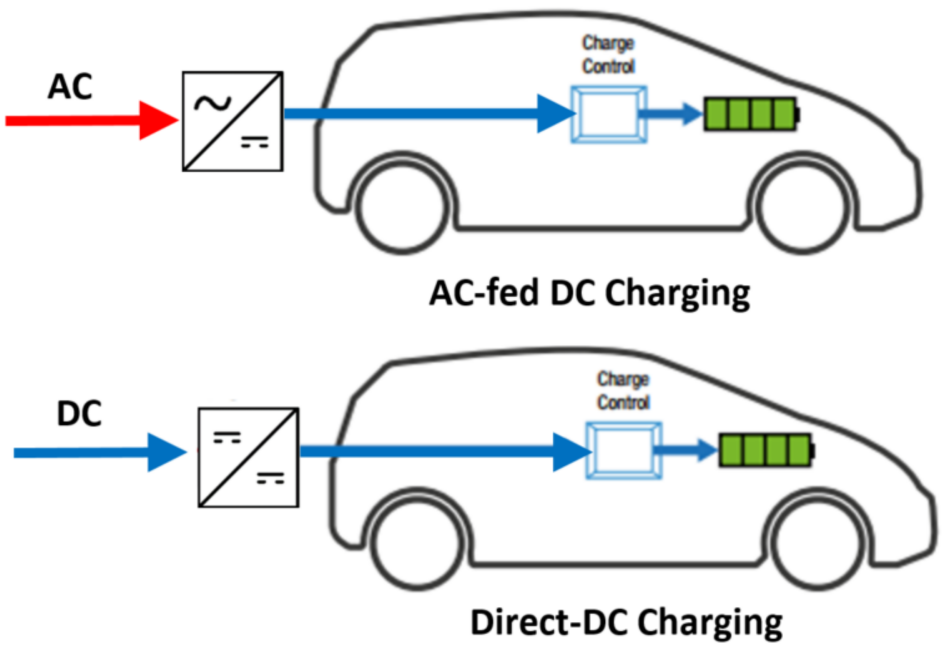

Figure 6. AC-fed versus direct-DC EV charging.

Apart from the lack of DC EVSE equipment on the market, voltage standards for both the supply side and the EV side would need to be developed and negotiated. Vehicle-toEVSE communication standards would need to accommodate a wide range of available DC power levels. For supply standards, it would be important to align any developed standards between the DC building industry and DC fast charger manufacturers. Further, to showcase the potential benefits of DC EV charging, existing and planned projects should demonstrate their efficiency and cost advantages compared to AC-input equipment.

\subsection{Residential Backup Power}

Residential DC backup power refers to a lightweight electronic solution that provides resiliency to the various user-selected critical loads in a home. Critical loads often include communication devices (e.g., a Wi-Fi router), refrigerators, security devices, medical devices, and select lights. For California in particular, garage door openers being sold are now required to have a backup battery, because many 2017 wildfire deaths were caused by the inability to escape during the grid outage [53]. These lightweight DC backup units contain ample storage and often include a solar input port. They operate at touch-safe voltages, rarely require permitting, and can often be installed by the customer.

Residential DC backup circuits have several advantages over AC alternatives. With AC distribution, there are two options for battery backup: using a separate battery in every critical load or using a dedicated uninterrupted power supply (UPS). However, backup batteries are less likely to be maintained regularly, and therefore more likely to fail. This is one advantage of using dedicated backup circuits with centralized storage 
that is distributed. The backup circuits' centralized AC/DC gateway converter has power electronics that enforce a one-way connection to the grid and can feature regulated portbased point-to-point power delivery. Point-to-point power distribution is only possible with DC and greatly eases the technical challenges of load management and shedding.

One example of a residential DC backup circuit is the Home Energy Router (HERo), which is currently under development [54]. The HERo (Figure 7) features ports for solar, storage, and DC loads via USB-A, USB-C, and PoE. The unit can eventually be designed to take dual AC or DC input. Its price-based controller can use machine learning to tune its optimization parameters in real-time and can monitor messages from grid operators.

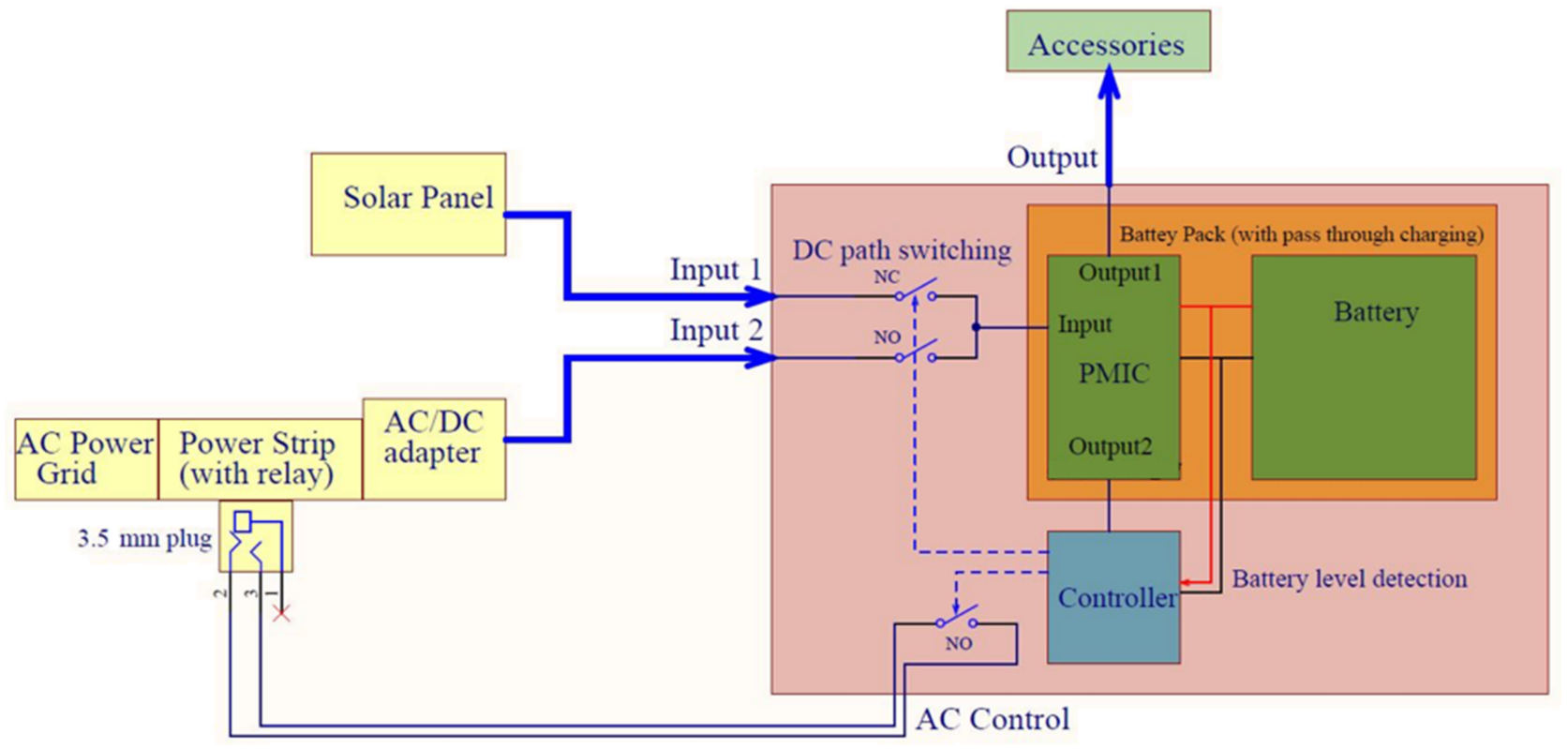

Figure 7. Statewide electrical Block diagram for the HERo. (Source: Belkin).

Residential DC backup circuits will have to demonstrate a clear market incentive beyond efficiency. The target customers are likely middle-income households, whose occupants will often want to install the backup units themselves. As such, the units must be as inexpensive, safe, and as easy to use as possible. These DC backup units will have to drive the DC end-use market because, in the current market, dual AC or DC loads likely will not exist without such a driver. In addition, users will have to assign load shedding prioritization manually, because power communications protocols do not currently identify devices and priority. One key marketing advantage over AC distributed backup batteries is the ability to connect a user-mounted solar panel, which will improve backup lifetime, reduce grid energy use, and potentially provide critical power during a grid outage.

\subsection{Community Microgrid}

Although the typical practice today is a behind-the-meter microgrid solution for single buildings with solar PV and storage, the community model has several potential advantages. This pathway involves a community microgrid that can operate in island mode, which connects multiple buildings and allows them to share the community's DER assets. The community includes a combination of commercial, residential, or both loads, with solar PV generation and battery storage. DC community microgrids feature a DC bus that connects to each building's electricity feeder. DERs can connect directly to the DC bus, and the buildings (end uses) within the microgrid can operate in island mode. While the DC microgrid would ideally serve DC loads within buildings, in the near future, an inverter is likely required for this pathway to come to fruition. The microgrid may have an interconnection with the grid for the import and export of energy through a 
central bidirectional gateway inverter. This pathway may be most appropriate for newly constructed ZE building communities.

While community microgrids can be AC, a DC topology offers many distinct advantages. First, DC-DC converters are inherently more efficient than DC-AC inverters [55]; therefore, eliminating the inverters for each DER connected to the microgrid improves overall distribution system efficiency. In addition, the manufacturing bill of materials is lower in a DC system, suggesting that the upfront cost of a DC system will be lower at economies of scale. The DC link eliminates the need for the DERs to synchronize in phase with each other or with the grid, greatly simplifying the control topology and allowing for highly distributed systems. Further, the microgrid's gateway inverter can perform grid services such as reactive power compensation. In the DC community microgrid configuration, DERs can be connected with the use of DC-DC converters to match the bus voltage, resulting in overall higher system reliability due to the fewer required power electronics, and better power quality, compared to a more traditional AC microgrid [56]. The project team has identified three installations based on this proposed pathway, and more are under planning or development.

Several other advantages make DC ideal for the scalability of a community microgrid. First, the microgrid could be designed such that the distribution feeder does not need to be upgraded. In a DC system, the power through the feeder is limited entirely by the size of the gateway inverter. Second, many community microgrids do not have the space for community storage assets, making highly distributed storage solutions ideal. However, highly distributed ( $\sim 10 \mathrm{~kW}$ or less) storage solutions are not available for AC microgrids, because there are currently no battery inverters that can grid-form together in parallel on the same bus. The prolific use of power electronics in DC microgrids easily allows for DC solutions with highly distributed storage. Finally, community microgrids would ideally control power-sharing between homes with co-optimization. The use of power electronics at every node makes DC the ideal topology for a highly controlled microgrid.

Perhaps the most prominent challenge to grid-connected DC community microgrids is uncertainty from regulatory bodies and electrical utilities, particularly for non-utilitybacked microgrids that may jeopardize the utility earnings and investment in existing electrical distribution [57]. DC community microgrids can be an excellent front-of-the-meter opportunity for utilities that accept the new technology. Front-of-the-meter solutions would also require extensive training for utility linemen to ensure operation. In contrast, behindthe-meter solutions would require operation and maintenance from the DC microgrid provider. Another challenge is in repurposing or augmenting the original AC infrastructure to support a DC microgrid. To support a DC microgrid, the existing wires will likely need to be reinforced to handle a higher current, because the $D C$ voltage is often lower than that of the original AC system. However, the main infrastructure challenge is the potential need for both $\mathrm{AC}$ and $\mathrm{DC}$ power distribution lines. This challenge arises in community retrofits where there are customers who do not want to participate. In this case, the infrastructure must support both $\mathrm{AC}$ and $\mathrm{DC}$ wires, leading to one of two expensive options. The first is to replace the poles with ones that are tall enough to accommodate the required clearance between the AC and DC wires. The other option is to underground the DC cables, which is more expensive but more elegant. In general, DC community microgrids are best suited for newly constructed neighborhoods. In particular, neighborhoods with ample yard space for individual or shared assets are ideal. Nonetheless, with the increasing demand for resiliency and EV charging, DC community microgrids may still be the most attractive solution for retrofits, despite the potentially higher upfront cost. Figure 8 shows a diagram of a group of buildings in an existing neighborhood block, some of which (shaded blue) are participating in the microgrid, while others have opted out. For more information and a case study on neighborhood microgrids, see https:/ / ecoblock.berkeley.edu) 


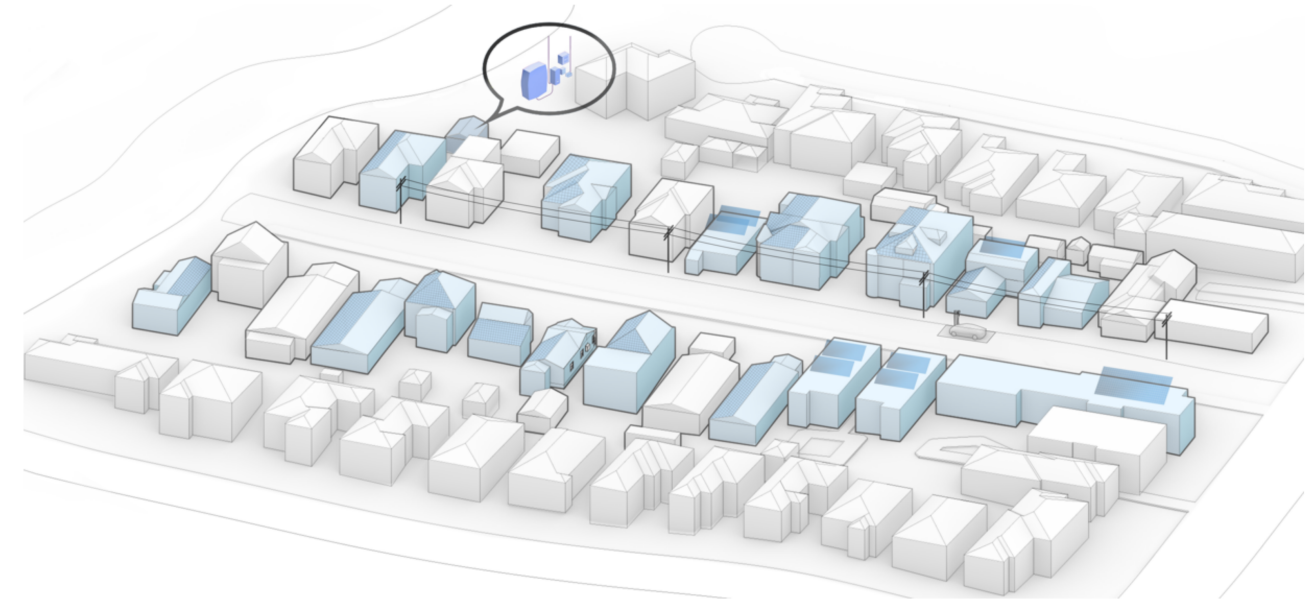

Figure 8. Community microgrid in an existing neighborhood setting (retrofit) (source: California Institute for Energy and Environment, UC Berkeley EcoBlock).

\subsection{Building-Integrated PV Powering Local End Uses}

Building-integrated PV (BIPV) refers to the integration of PV cells into a building's facade, which often includes windows, awnings, and outward-facing concrete. It differs from building-applied PV (BAPV) in that the PV is integrated during construction, rather than applied afterward. BIPV is often connected to a building's main distribution panel via a string inverter. However, module-level microinverters will likely become more popular for AC BIPV systems because building facades are much more susceptible to panel mismatch than roof-mounted panels [58]. For DC systems, power optimizers also solve this problem and may be the pathway for connecting loads directly to BIPV systems. These systems can easily include close-proximity loads, such as window blinds, window openers, electrochromic windows, occupancy and daylight sensors, and interior lighting. Figure 9 shows a conceptual schematic for a direct-DC BIPV system.

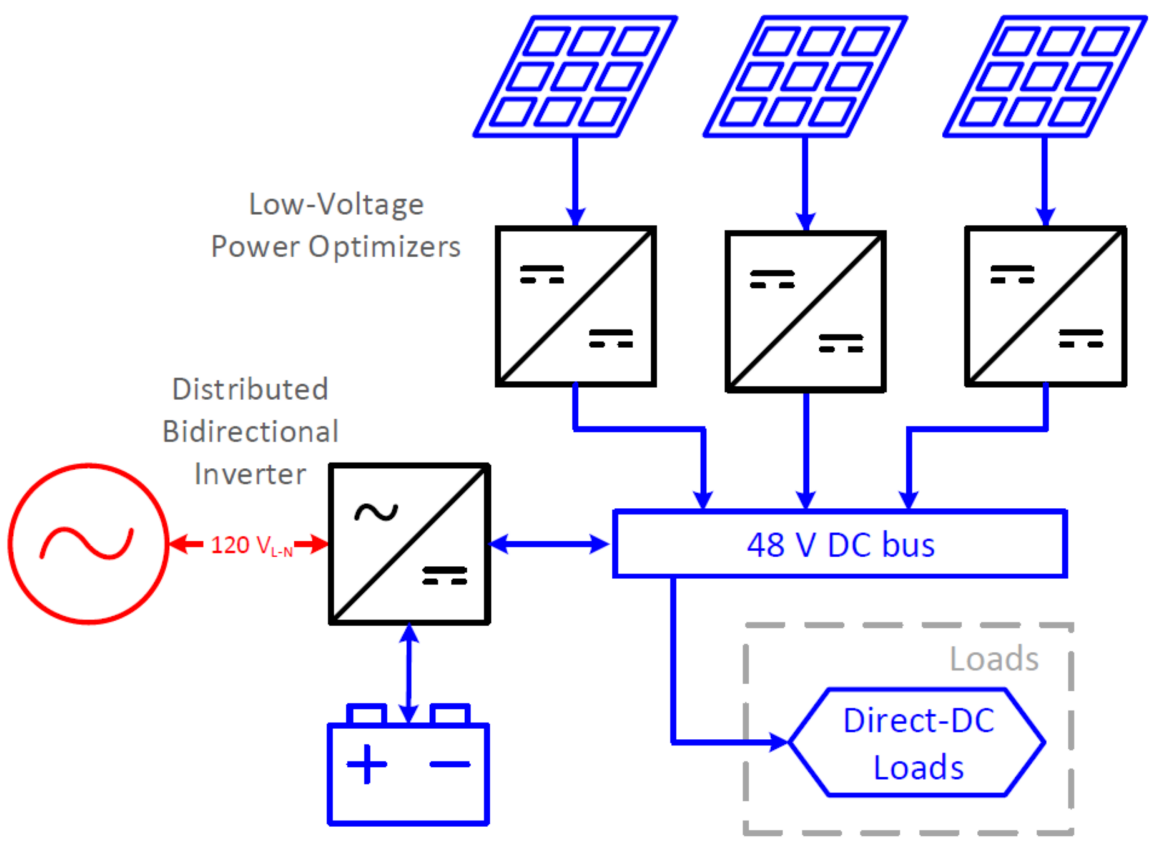

Figure 9. Direct-DC BIPV system powering local end uses.

Recent studies have suggested BIPV should be integrated via parallel power optimizers connected by low-voltage DC distribution [59]. Module-level converters are ideal due to voltage mismatch. While power optimizers can be superior to microinverters in 
cost and efficiency, the key metric of comparison is life span, because it is very difficult to replace modules and converters. DC power optimizers require fewer electrolytic capacitors, resulting in a slightly longer life span than AC microinverters. However, it is important to use parallel power optimizers because a single failure in a series power optimizer string disables the entire string. Parallel power optimizers are conducive to low-voltage DC $(<60 \mathrm{~V})$, allowing such BIPV systems to be installed by construction workers without the need for a licensed electrician. Low-voltage DC systems are also immune to AC disturbances and have additional options for grounding and isolation, which further helps to increase the BIPV system's life span [59]. Because a BIPV installation may involve many separate elements, being able to connect them via low-power DC, rather than with AC circuits, should have a significant advantage in cost, cable size, and installation complications (e.g., building shell penetrations). This also holds for low-power devices in and near the building facade. Matching the energy needs of in-facade devices to BIPV production, often with the use of electricity storage, can greatly reduce the capacity needed for a connection to the AC system. The energy use of in-facade devices will also be reduced by being directly DC-powered.

Because parallel power optimizers are ideal for BIPV systems, it can make sense to add certain loads to the BIPV circuit. The system's gateway inverter must be low-cost but bidirectional so that these loads can be powered in absence of sunlight. Although the easiest pathway is to add close-proximity loads to the BIPV circuit, loads such as window shades, openers, and electrochromic windows are not significantly impactful pathways. For the greatest impact, the BIPV circuit should connect to larger loads, such as a lighting circuit, in-façade HVAC, or DC power hub. The latter are available from various manufacturers. Another recommendation is to integrate communications on the DC circuit for connected end uses, such as sensors, cameras, and actuators, which may be beneficial not just from a resilience perspective, but also from a security perspective.

\section{Conclusions and Discussion}

In this paper, we identified and elaborated on specific adoption pathways for DC distribution systems in buildings. Each pathway represents technology that can be implemented today, but with tomorrow's energy and building landscape in mind. Table 6 shows a qualitative summary of the proposed DC adoption pathways based on findings from the technology review, market assessment, energy efficiency analysis, and expert feedback.

Table 6. Evaluation of the proposed adoption pathways.

\begin{tabular}{|c|c|c|c|c|c|}
\hline \# & Adoption Pathway & Technology Readiness & Market Readiness & Resilience Benefits & $\begin{array}{l}\text { Energy Savings } \\
\text { Potential }\end{array}$ \\
\hline 1 & Office workstations & 决块 & t次 & $\star *$ & 勀次 \\
\hline 2 & PoE lighting & 她地 & 她比 & $\star$ & t女 \\
\hline 3 & EV charging & t & * & 她比 & 战 \\
\hline 4 & Residential backup power & $t *$ & $\star$ & 战 & 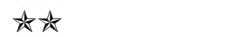 \\
\hline 5 & Community microgrid & t文 & t & 蚁地 & t \\
\hline 6 & BIPV powering local end uses & t虾 & $\star *$ & 如 & t块 \\
\hline
\end{tabular}

Each of these adoption pathways is appropriate for specific building types and applications and is dependent on evolving technology standards and equipment market availability. Individual project success is also determined by jurisdiction constraints and opportunities, such as local building codes, utility policies, and efficiency incentives, as well as DC system developer capabilities and expertise.

Another important factor in the success of DC distribution systems is the interoperability of EUDs, power system components, and controls. Today, engineers, consultants, system integrators, and vendors are responsible for analyzing and designing new DC microgrids (e.g., system/wire sizing, protection schemes, control system design, and equipment configuration) with various, fragmented, and sometimes proprietary software packages to 
overcome the challenges imposed by such designs. Once the system design is complete, equipment selection and configuration to manage loads, generation, and power quality begin. To ensure interoperability, engineers must communicate extensively with various vendors to ensure their equipment can meet the project goals. This process typically relies on networking within the industry, which can be extremely inefficient and time-consuming and can cause delays in the adoption, advancement, and deployment of projects.

In addition, to accommodate the installation of DC technologies and realize installation and other cost savings, it will be necessary to update related regulations and technology standards. However, the installation of low-voltage DC wiring by non-electricians has become a point of contention, as electrician industry groups have advocated for full electrician licenses when installing low-voltage lighting [60]. In 2019 alone, legislation was introduced in 23 states to modify code or licensing to require technologies such as PoE to be installed by fully licensed electricians. Though the legislation stalled or was modified in many states after advocacy by low-voltage industry groups, this is expected to be an ongoing issue as states, counties, and municipalities modify their requirements to accommodate the technologies.

Finally, as a recommendation for future work, and to help overcome the barrier of product availability, the project team recommends the development of EUDs that accept DC and $\mathrm{AC}$ at the input. The internal operation of many EUDs is agnostic to the input type and often works at a different voltage or even frequency than what is supplied by the electric grid. With modification to the power input stage of the device, many widely available devices could be converted to universal-input devices (UIDs) that could operate on both AC and DC input. The availability of UIDs could enable more mainstream adoption of DC distribution in buildings until DC-specific devices reach economies of scale and become mainstream products for manufacturers. The cost to consumers of these upgrades could be lower than custom-designed, DC-compatible equipment. Manufacturers could also benefit from designing UIDs, as they would be able to utilize the same end-use components for a wider spectrum of markets.

Figure 10 shows a conceptual schematic of a UID. Electronics often use a power-factorcorrection flyback converter to convert AC to low-voltage DC. The power-factor-correction flyback's controller can be modified to sense and process a DC input, allowing the same hardware to connect to AC or DC. Of course, the device would have to be sized to handle the highest voltage and current ratings of either.

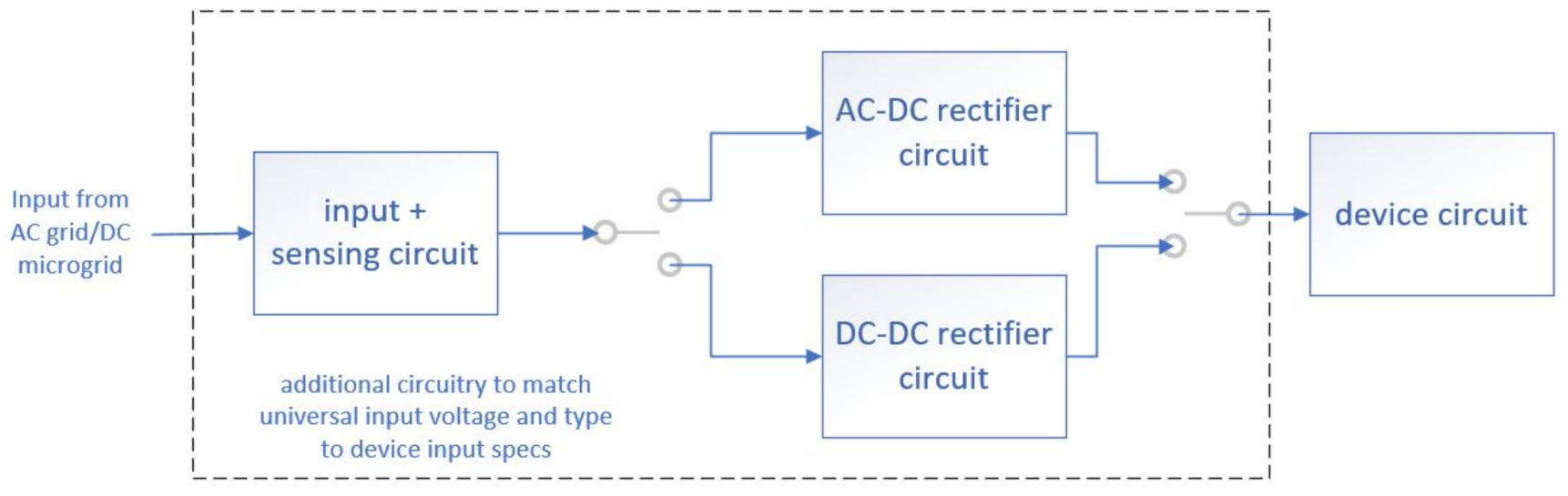

Figure 10. Conceptual design of a universal input device modification.

Author Contributions: Conceptualization, V.V. and R.B.; methodology, V.V., M.G.-T., B.N., W.B.H. and S.M.F.; expert elicitation and market review, V.V., A.S., O.G., D.L.G., M.G.-T. and S.M.F.; efficiency analysis, D.L.G.; adoption pathways, V.V., D.L.G., B.N., W.B.H., O.G. and G.A.; writing—original draft preparation, V.V., D.L.G., M.G.-T.; review and editing, V.V., W.B.H. and S.M.F.; project administration, R.B. and W.B.H. All authors have read and agreed to the published version of the manuscript. 
Funding: Funding for this work was provided by the Assistant Secretary for Energy Efficiency and Renewable Energy, Building Technologies Office of the U.S. Department of Energy. This work was authored in part by Lawrence Berkeley National Laboratory, operated for the U.S. Department of Energy (DOE) under Contract No. DE-AC02-05CH11231, and in part by the National Renewable Energy Laboratory, operated by Alliance for Sustainable Energy, LLC, for the DOE under Contract No. DE-AC36-08GO28308. Funding was provided by the DOE Assistant Secretary for Energy Efficiency and Renewable Energy Building Technologies Office Emerging Technologies Program. The views expressed in the article do not necessarily represent the views of the DOE or the U.S. Government.

Informed Consent Statement: Informed consent was obtained from all subjects involved in the study.

Acknowledgments: The authors would like to thank Dusan Brhlik and Michael Deru for technical input and review of the manuscript, and Susannah Shoemaker for editing the manuscript.

Conflicts of Interest: The authors declare no conflict of interest.

\section{References}

1. Barbose, G.; Darghouth, N.; Elmallah, S.; Forrester, S.; Kristina, S.H.K.; Millstein, D.; Rand, J.; Cotton, W.; Sherwood, S.; O'Shaughnessy, E. Tracking the Sun: Pricing and Design Trends for Distributed Photovoltaic Systems in the United States, 2019 ed.; Lawrence Berkeley National Laboratory: Berkeley, CA, USA, 2019.

2. Wood Mackenzie Power \& Renewables; U.S. Energy Storage Association. “U.S. Energy Storage Monitor. Q4 2020 Executive Summary" Dec. 2020. Available online: http://go.woodmac.com/1/131501/2020-12-02/2mxrn4/131501/1606920186iLulZaUA/ WoodMac_US_ESM_Q4_2020_Executive_Summary.pdf (accessed on 9 December 2021).

3. Garbesi, K.; Vossos, V.; Shen, H. Catalog of DC Appliances and Power Systems; Lawrence Berkeley National Laboratory: Berkeley, CA, USA, 2011.

4. Gerber, D.L.; Vossos, V.; Feng, W.; Marnay, C.; Nordman, B.; Brown, R. A simulation-based efficiency comparison of AC and DC power distribution networks in commercial buildings. Appl. Energy 2018, 210, 1167-1187. [CrossRef]

5. Denkenberger, D.; Driscoll, D.; Lighthiser, E.; May-Ostendorp, P.; Trimboli, B.; Walters, P. DC Distribution Market, Benefits, and Opportunities in Residential and Commercial Buildings; Pacific Gas \& Electric Company: San Francisco, CA, USA, 2012.

6. Fregosi, D.; Ravula, S.; Brhlik, D.; Saussele, J.; Frank, S.; Bonnema, E.; Scheib, J.; Wilson, E. A comparative study of DC and AC microgrids in commercial buildings across different climates and operating profiles. In Proceedings of the 2015 IEEE First International Conference on DC Microgrids (ICDCM), Atlanta, GA, USA, 7-10 June 2015; pp. 159-164.

7. Boeke, U.; Wendt, M. DC power grids for buildings. In Proceedings of the 2015 IEEE First International Conference on DC Microgrids (ICDCM), Atlanta, GA, USA, 7-10 June 2015; pp. 210-214.

8. Noritake, M.; Yuasa, K.; Takeda, T.; Hoshi, H.; Hirose, K. Demonstrative research on DC microgrids for office buildings. In Proceedings of the 2014 IEEE 36th International Telecommunications Energy Conference (IN ${ }^{T E L}$ EC), Sao Paulo, Brazil, 17-20 August 2014; pp. 1-5.

9. Glasgo, B.; Azevedo, I.L.; Hendrickson, C. How much electricity can we save by using direct current circuits in homes? Understanding the potential for electricity savings and assessing feasibility of a transition towards DC powered buildings. Appl. Energy 2016, 180, 66-75. [CrossRef]

10. Vossos, V.; Gerber, D.; Bennani, Y.; Brown, R.; Marnay, C. Techno-economic analysis of DC power distribution in commercial buildings. Appl. Energy 2018, 230, 663-678. [CrossRef]

11. Castillo-Calzadilla, T.; Macarulla, A.M.; Kamara-Esteban, O.; Borges, C.E. Analysis and assessment of an off-grid services building through the usage of a DC photovoltaic microgrid. Sustain. Cities Soc. 2018, 38, 405-419. [CrossRef]

12. Che, L.; Shahidehpour, M. DC Microgrids: Economic Operation and Enhancement of Resilience by Hierarchical Control. IEEE Trans. Smart Grid 2014, 5, 2517-2526. [CrossRef]

13. George, K. DC Power Production, Delivery, and Utilization; Electric Power Research Institute: Washington, DC, USA, 2006.

14. Gal, I.; Lipson, B.; Larsen, T.; Tsisserev, A.; Mereuta, J. DC Microgrids in Buildings; CSA Group: Toronto, ON, Canada, 2019 ; p. 45.

15. Vossos, V.; Johnson, K.; Kloss, M.; Heard, R.; Gerber, D.; Nordman, B.; Mannarino, E.; Khattar, M.; Brown, R. Direct Current as an Integrating and Enabling Platform for Zero-Net Energy Buildings; California Energy Commission: Sacramento, CA, USA, 2019.

16. Fortenbery, B.; Ton, M.; Tschudi, W. DC Power for Improved Data Center Efficiency; Lawrence Berkeley National Laboratory: Berkeley, CA, USA, 2008.

17. AlLee, G.; Tschudi, W. Edison Redux: 380 Vdc Brings Reliability and Efficiency to Sustainable Data Centers. IEEE Power Energy Mag. 2012, 10, 50-59. [CrossRef]

18. Desu, A.; Puvvadi, U.; Stachecki, T.; Case, S.; Ghose, K. AC vs. Hybrid AC/DC Powered Data Centers: A Workload Based Perspective. In Proceedings of the 2019 IEEE 17th International Conference on Industrial Informatics (INDIN), Helsinki-Espoo, Finland, 22-25 July 2019; pp. 1411-1418.

19. Becker, D.J.; Sonnenberg, B.J. DC Microgrids in Buildings and Data Centers. In Proceedings of the 2011 IEEE 33rd International Telecommunications Energy Conference (IN ${ }^{T E L}$ EC), Amsterdam, The Netherlands, 9-13 October 2011; pp. 1-7. 
20. Thomas, B.A.; Azevedo, I.L.; Morgan, G. Edison Revisited: Should we use DC circuits for lighting in commercial buildings? Energy Policy 2012, 45, 399-411. [CrossRef]

21. Frank, S.; Bonnema, E.; Scheib, J.; Wilson, E. Energy Savings Analysis for a Novel DC Microgrid Platform for High Bay Lighting Systems; National Renewable Energy Laboratory: Golden, CO, USA, 2015.

22. Aguilar, F.; Crespí-Llorens, D.; Quiles, P.V. Techno-economic analysis of an air conditioning heat pump powered by photovoltaic panels and the grid. Sol. Energy 2019, 180, 169-179. [CrossRef]

23. Capasso, C.; Veneri, O. Experimental study of a DC charging station for full electric and plug in hybrid vehicles. Appl. Energy 2015, 152, 131-142. [CrossRef]

24. Siraj, K.; Khan, H.A. DC distribution for residential power networks-A framework to analyze the impact of voltage levels on energy efficiency. Energy Rep. 2020, 6, 944-951. [CrossRef]

25. Strategen Consulting. ARUP Group Direct-Current Scoping Study: Opportunities for Direct Current Power in the Built Environment; U.S. Department of Energy, Building Technologies Office: Washington, DC, USA, 2014.

26. Glasgo, B.; Azevedo, I.L.; Hendrickson, C. Expert assessments on the future of direct current in buildings. Environ. Res. Lett. 2018, 13, 074004. [CrossRef]

27. Aloise-Young, P.A.; Ross, E.C.; Dickmann, E.M.; Cross, J.E.; Zimmerle, D.; Nobe, M.C. Overcoming barriers to direct current power: Lessons learned from four commercial building case studies. Energy Effic. 2020, 14, 10. [CrossRef]

28. Marchionini, B.; Zheng, S. Direct Current in Buildings: A Look at Current and Future Trends; National Electrical Manufacturers Association: Rosslyn, VA, USA, 2018; p. 27.

29. Pantano, S.; May-Ostendorp, P.; Dayem, K. Demand DC: Accelerating the Introduction of DC Power in the Home; CLASP and Xergy Consulting: Washington, DC, USA, 2016; p. 27.

30. Vossos, V.; Gaillet-Tournier, M.; Gerber, D.; Nordman, B.; Brown, R.; Bernal, W.; Ghatpande, O.; Saha, A.; Deru, M.; Frank, S. Direct-DC Power in Buildings: Identifying the Best Applications Today for Tomorrow's Building Sector. In Proceedings of the ACEEE Summer Study on Energy Efficiency in Buildings, ACEEE, Pacific Grove, CA, USA; 2020; p. 15.

31. Gerber, D.L.; Liou, R.; Brown, R. Energy-Saving Opportunities of Direct-DC Loads in Buildings. Appl. Energy 2019, 248, 274-287. [CrossRef]

32. Sabry, A.H.; Shallal, A.H.; Hameed, H.S.; Ker, P.J. Compatibility of household appliances with DC microgrid for PV systems. Heliyon 2020, 6, e05699. [CrossRef] [PubMed]

33. Gu, L.; Ruan, X.; Xu, M.; Yao, K. Means of eliminating electrolytic capacitor in AC/DC power supplies for LED lightings. IEEE Trans. Power Electron. 2009, 24, 1399-1408. [CrossRef]

34. Chen, W.; Hui, S.R. Elimination of an electrolytic capacitor in AC/DC light-emitting diode (LED) driver with high input power factor and constant output current. IEEE Trans. Power Electron. 2012, 27, 1598-1607. [CrossRef]

35. Gerber, D.L.; Le, C.; Kline, M.; Kinget, P.R.; Sanders, S.R. An Integrated Multilevel Converter With Sigma-Delta Control for LED Lighting. IEEE Trans. Power Electron. 2019, 34, 3030-3040. [CrossRef]

36. Saidur, R.; Mekhilef, S.; Ali, M.B.; Safari, A.; Mohammed, H. Applications of variable speed drive (VSD) in electrical motors energy savings. Renew. Sustain. Energy Rev. 2012, 16, 543-550.

37. Christensen, K.; Nordman, B. Back to the future: A need for multi-drop Ethernet for cost-effective power distribution. In Proceedings of the 39th Annual IEEE Conference on Local Computer Networks, Edmonton, AB, Canada, 8-11 September 2014; pp. 378-381.

38. Moussa, S.; Ghorbal, M.J.-B.; Slama-Belkhodja, I. Bus voltage level choice for standalone residential DC nanogrid. Sustain. Cities Soc. 2019, 46, 101431. [CrossRef]

39. Yseboodt, L.; Abramson, D. Overview of 802.3bt-Power over Ethernet Standard; Ethernet Alliance: Beaverton, OR, USA, 2019.

40. EMerge Alliance Data/Telecom. Available online: https://www.emergealliance.org/standards/data-telecom/ (accessed on 12 December 2021).

41. Prabhala, V.A.; Baddipadiga, B.P.; Fajri, P.; Ferdowsi, M. An Overview of Direct Current Distribution System Architectures \& Benefits. Energies 2018, 11, 2463. [CrossRef]

42. Fujitsu Component Development of DC Plugs and Socket Outlets for Smart Grid and Data Center. Available online: http: //www.fujitsu.com/jp/group/fcl/en/resources/news/press-releases/2010/20101109-1.html (accessed on 12 January 2016).

43. DOE Commercial Reference Buildings. Available online: https://energy.gov/eere/buildings/commercial-reference-buildings (accessed on 12 December 2021).

44. NREL PVWatts Calculator. 2020. Available online: https://pvwatts.nrel.gov/pvwatts.php (accessed on 12 December 2021).

45. Santos, A.; Cale, J.; Othee, A.; Gerber, D.; Frank, S.; Duggan, G.; Zimmerle, D.; Brown, R. Comparison of Load Models for Estimating Electrical Efficiency in DC Microgrids. In Proceedings of the 3rd IEEE International Conference on DC Microgrids, Matsue, Japan, 20-23 May 2019.

46. Gerber, D.L.; Ghatpande, O.A.; Nazir, M.; Heredia, W.G.B.; Feng, W.; Brown, R.E. Energy and power quality measurement for electrical distribution in AC and DC microgrid buildings. Appl. Energy 2022, 308, 118308. [CrossRef]

47. Vossos, V.; Garbesi, K.; Shen, H. Energy Savings from Direct-DC in U.S. Residential Buildings. Energy Build. 2014, 68, 223-231. [CrossRef]

48. Arnold, G.; Pennell, G. DC Lighting and Building Microgrids: Opportunities and Recommendations; Pacific Northwest National Laboratory: Richland, WA, USA, 2020; p. 12. 
49. Single Pair Ethernet: Welcome to the Future I Networking Solutions. Versa Technology. 2021. Available online: https: //www.versatek.com/single-pair-ethernet-welcome-to-the-future/ (accessed on 12 December 2021).

50. Boscaino, V.; Guerrero, J.M.; Ciornei, I.; Meng, L.; Riva Sanseverino, E.; Zizzo, G. Online optimization of a multi-conversion-level DC home microgrid for system efficiency enhancement. Sustain. Cities Soc. 2017, 35, 417-429. [CrossRef]

51. Harper, A.; Graeber, K. DC Lighting Systems Evaluation. Lighting Des. Appl. 2020, 50, 56-59.

52. Gerber, D.L.; Vossos, V.; Feng, W.; Khandekar, A.; Marnay, C.; Nordman, B. A simulation based comparison of AC and DC power distribution networks in buildings. In Proceedings of the 2017 IEEE Second International Conference on DC Microgrids (ICDCM), Nuremburg, Germany, 27-29 June 2017; pp. 588-595. [CrossRef]

53. SB 969. 2018. Available online: https://leginfo.legislature.ca.gov/faces/billTextClient.xhtml?bill_id=201720180SB969 (accessed on 12 December 2021).

54. Meier, A.; Brown, R.E.; Gerber, D.; Khandekar, A.; Kloss, M.; Koyanagi, H.; Liou, R.; Rainer, L.; Sanders, S. Efficient and Zero Net Energy-Ready Plug Loads; California Energy Comission: Sacramento, CA, USA, 2019.

55. Gerber, D.L.; Musavi, F. AC vs. DC Boost Converters: A Detailed Conduction Loss Comparison. In Proceedings of the Third International Conference on DC Microgrids (ICDCM), Shimane, Japan, 20-23 May 2019.

56. Sasidharan, N.; Singh, J.G. A resilient DC community grid with real time ancillary services management. Sustain. Cities Soc. 2017, 28, 367-386. [CrossRef]

57. Hoffman, S.; Carmichael, C. Six Barriers to Community Microgrids and Potential Ways Developers can Sumount Them; Hoffman Power Consulting: Johannesburg, South Africa, 2020.

58. Ravyts, S.; Vecchia, M.D.; Van den Broeck, G.; Yordanov, G.H.; Gonçalves, J.E.; Moschner, J.D.; Saelens, D.; Driesen, J. Embedded BIPV module-level DC/DC converters: Classification of optimal ratings. Renew. Energy 2020, 146, 880-889. [CrossRef]

59. Ravyts, S.; Dalla Vecchia, M.; Van den Broeck, G.; Driesen, J. Review on Building-Integrated Photovoltaics Electrical System Requirements and Module-Integrated Converter Recommendations. Energies 2019, 12, 1532. [CrossRef]

60. Tellas, R. Installing PoE Cable: Why We All Should Pay Attention to State Legislation. 7 November 2019. Available online: https:/ / www.belden.com/blog/smart-building/installing-poe-cable-state-legislation (accessed on 22 June 2021). 